\title{
Physical-chemical characterisation of the particulate matter inside two road tunnels in the São Paulo Metropolitan Area
}

\author{
J. Brito ${ }^{1}$, L. V. Rizzo ${ }^{2}$, P. Herckes ${ }^{3}$, P. C. Vasconcellos ${ }^{4}$, S. E. S. Caumo ${ }^{4}$, A. Fornaro ${ }^{5}$, R. Y. Ynoue ${ }^{5}$, P. Artaxo ${ }^{1}$, and \\ M. F. Andrade ${ }^{5}$ \\ ${ }^{1}$ Physics Institute, University of São Paulo, Brazil \\ ${ }^{2}$ Department of Earth and Exact Sciences, Federal University of São Paulo, Brazil \\ ${ }^{3}$ Department of Chemistry and Biochemistry, Arizona State University, Tempe, USA \\ ${ }^{4}$ Chemistry Institute, University of São Paulo, Brazil \\ ${ }^{5}$ Institute of Astronomy, Geophysics, and Atmospheric Sciences, University of São Paulo, Brazil
}

Correspondence to: J. Brito (jbrito@if.usp.br)

Received: 24 June 2013 - Published in Atmos. Chem. Phys. Discuss.: 9 August 2013

Revised: 18 November 2013 - Accepted: 19 November 2013 - Published: 17 December 2013

\begin{abstract}
The notable increase in biofuel usage by the road transportation sector in Brazil during recent years has significantly altered the vehicular fuel composition. Consequently, many uncertainties are currently found in particulate matter vehicular emission profiles. In an effort to better characterise the emitted particulate matter, measurements of aerosol physical and chemical properties were undertaken inside two tunnels located in the São Paulo Metropolitan Area (SPMA). The tunnels show very distinct fleet profiles: in the Jânio Quadros (JQ) tunnel, the vast majority of the circulating fleet are light duty vehicles (LDVs), fuelled on average with the same amount of ethanol as gasoline. In the Rodoanel (RA) tunnel, the particulate emission is dominated by heavy duty vehicles (HDVs) fuelled with diesel (5\% biodiesel). In the JQ tunnel, $\mathrm{PM}_{2.5}$ concentration was on average $52 \mu \mathrm{g} \mathrm{m}^{-3}$, with the largest contribution of organic mass (OM, $42 \%)$, followed by elemental carbon (EC, $17 \%)$ and crustal elements (13\%). Sulphate accounted for $7 \%$ of $\mathrm{PM}_{2.5}$ and the sum of other trace elements was $10 \%$. In the RA tunnel, $\mathrm{PM}_{2.5}$ was on average $233 \mu \mathrm{g} \mathrm{m}^{-3}$, mostly composed of EC (52\%) and OM (39\%). Sulphate, crustal and the trace elements showed a minor contribution with $5 \%, 1 \%$, and $1 \%$, respectively. The average OC: EC ratio in the JQ tunnel was $1.59 \pm 0.09$, indicating an important contribution of EC despite the high ethanol fraction in the fuel composition. In the RA tunnel, the OC: EC ratio was $0.49 \pm 0.12$, consistent with previous measurements of diesel-fuelled HDVs. Besides bulk car-
\end{abstract}

bonaceous aerosol measurement, polycyclic aromatic hydrocarbons (PAHs) were quantified. The sum of the PAHs concentration was $56 \pm 5 \mathrm{ng} \mathrm{m}^{-3}$ and $45 \pm 9 \mathrm{ng} \mathrm{m}^{-3}$ in the RA and JQ tunnel, respectively. In the JQ tunnel, benzo(a)pyrene (BaP) ranged from 0.9 to $6.7 \mathrm{ng} \mathrm{m}^{-3}\left(0.02-0.1 \%\right.$ of $\left.\mathrm{PM}_{2.5}\right)$ whereas in the RA tunnel BaP ranged from 0.9 to $4.9 \mathrm{ng} \mathrm{m}^{-3}$ (0.004-0. 02\%o of $\mathrm{PM}_{2.5}$ ), indicating an important relative contribution of LDVs emission to atmospheric $\mathrm{BaP}$.

Real-time measurements performed in both tunnels provided aerosol size distributions and optical properties. The average particle count yielded $73000 \mathrm{~cm}^{-3}$ in the JQ tunnel and $366000 \mathrm{~cm}^{-3}$ in the RA tunnel, with an average diameter of $48 \mathrm{~nm}$ in the former and $39 \mathrm{~nm}$ in the latter. Aerosol single scattering albedo, calculated from scattering and absorption observations in the JQ tunnel, indicates a value of 0.5 associated with LDVs. Such single scattering albedo is $20-50 \%$ higher than observed in previous tunnel studies, possibly as a result of the large biofuel usage. Given the exceedingly high equivalent black carbon loadings in the RA tunnel, real time light absorption measurements were possible only in the JQ tunnel. Nevertheless, using EC measured from the filters, a single scattering albedo of 0.31 for the RA tunnel has been estimated. The results presented here characterise particulate matter emitted from nearly 1 million vehicles fuelled with a considerable amount of biofuel, providing a unique experimental site worldwide. 


\section{Introduction}

Megacities, large urban conglomerates with a population of 10 million or more inhabitants, are increasingly receiving attention as strong pollution hotspots with significant global impact (Gurjar et al., 2008; Beirle et al., 2011; Butler et al., 2012). The emissions from such large centres in both the developed and developing parts of the world are strongly impacted by the transportation sector. The São Paulo Metropolitan Area (SPMA), located in the southeast of Brazil, is a megacity with a population of 19 million people and 7.4 million vehicles, many of which are fuelled by a considerable amount of ethanol. Such a fleet is considered a unique case of large-scale biofuel usage worldwide. Despite the large impact on human health and atmospheric chemistry dynamics, many uncertainties are found in terms of gas and particulate matter emissions from vehicles and their atmospheric reactivity, e.g. secondary organic aerosol formation (de Abrantes et al., 2009; Ferreira da Silva et al., 2010; Kirstine and Galbally, 2012).

Ethanol was first introduced as a commercial alternative to fossil fuels in Brazil in the early 1980s and its use has strongly increased since the 2000s. This is essentially due to a new generation of flexible fuel vehicles (FFV), introduced in 2003, capable of using any rate of anhydrous ethanol from $20 \%$ (mixed with gasoline, hereafter named gasohol) to pure hydrous ethanol. In 2011 the consumption of ethanol in São Paulo state was 8300 millions $\mathrm{m}^{3}$ whereas gasoline was 7500 millions $\mathrm{m}^{3}$, according to the Brazilian National Agency of Petroleum, Natural Gas and Biofuels (Fig. 1). Currently, roughly $85 \%$ of all new light duty vehicles (LDV) are FFV, which, combined with the current economic expansion, results in a fast changing light duty vehicle fleet. Whereas heavy duty vehicles (HDVs) are renewed much slower (the vehicles are on average more than $10 \mathrm{yr}$ old), the diesel composition has considerably changed in the past years. Combined with significant reduction in sulphur content towards $10 \mathrm{ppm}$, the minimum biodiesel content was set to $2 \%$ in 2008 and $5 \%$ in 2010.

Tunnel measurements are a powerful tool for characterising vehicular emissions under real driving conditions (Martins et al., 2006; Handler et al., 2008; Ho et al., 2009; Cheng et al., 2010). Unlike tailpipe emission measurements conducted on a chassis dynamometer (Mulawa et al., 1997; Kleeman et al., 2000), tunnel studies allow the characterisation of exhaust emissions, along with the mechanical wear of tires and brakes (Rogge et al., 1993a; Garg et al., 2000), and the ejection of particles from the pavement (Kupiainen et al., 2005) by resuspension processes (Nicholson et al., 1989; Sternbeck et al., 2002). Knowledge of emission source profiles of such fast-changing fleet and/or fuel composition is a crucial step for accurate interpretation of receptor modelling analysis.

Besides the identification of organic compounds and trace elements from vehicular sources, quantification of the emit-

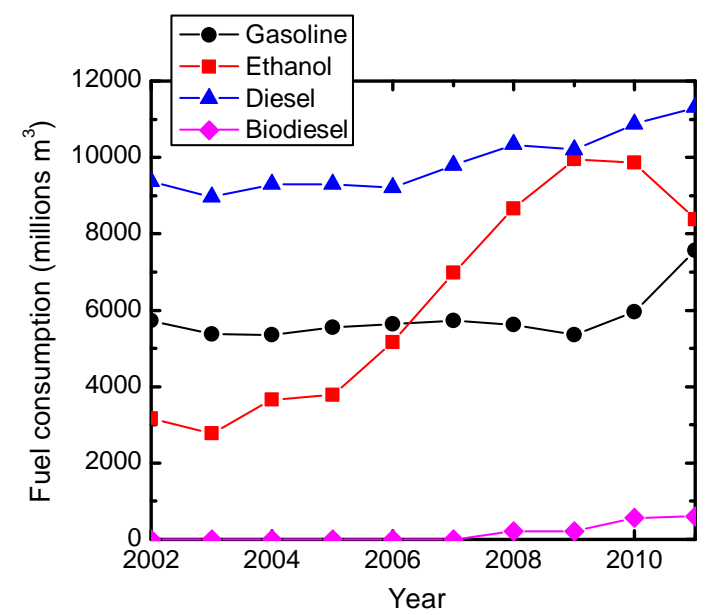

Fig. 1. Fuel consumption in the São Paulo state. Data from the Brazilian National Agency of Petroleum, Natural Gas and Biofuels. The indicated ethanol is the sum of anhydrous (part of gasohol) and hydrous (E100). The biodiesel consumption was calculated considering its minimum content in diesel: $2 \%$ in 2008-2009 and 5\% 2010-2011.

ted carbonaceous aerosol is fundamental for the analysis and interpretation of urban ambient measurements (Pio et al., 2011; El Haddad et al., 2011; Daher et al., 2013). Carbonaceous aerosol is commonly divided into an organic carbon (OC) and an elemental carbon (EC) fraction. While the only source of EC is direct emission from burning of carbonaceous matter, OC may be emitted in the particulate phase or formed through gas-to-particle conversion processes in the atmosphere (Jones and Harrison, 2005; Saylor et al., 2006). EC is a good tracer for emissions from fossil fuel combustion, namely urban emissions from road transport. Other EC sources such as biomass burning emit at much lower rates and are relevant, on a local scale, only in wild fires events or wintertime in rural or urban areas (Gelencsér et al., 2007). Primary OC may result from biomass burning, biological particles, plant debris or from fossil fuel.

Here we present the physical and chemical characterisation of the particulate matter inside two tunnels in the SPMA with very distinct circulating fleets. In one tunnel, LDVs and motorcycles account for $99.3 \%$ of the circulating fleet, whereas in the other a significant fraction $(\sim 30 \%)$ of overall traffic is composed of HDVs. The analysis includes aerosol size distribution, optical properties, elemental composition, quantification of polycyclic aromatic hydrocarbons (PAHs) and organic and elemental carbon (OC: EC) concentrations. 
Table 1. List of instrumentation used in this study

\begin{tabular}{lll}
\hline Instrument & Parameter measured & Time resolution \\
\hline TSI Scanning Mobility Particle Sizer, model 3080 & Aerosol size distribution 10-430 $\mathrm{nm}$ & $5 \mathrm{~min}$ \\
3- $\lambda$ TSI Nephelometer, model 3563 & Aerosol light scattering & $5 \mathrm{~min}$ \\
Thermo MAAP, model 5012 & Aerosol light absorption, EBC & $1 \mathrm{~min}$ \\
GC-FID Varian, model 3800 & Particle phase PAHs & $12 \mathrm{~h}$ \\
XR-F PANalytical, model Epsilon 5 & Elemental composition & $12 \mathrm{~h}$ \\
Sunset OCEC analyserc & Organic and elemental carbon & $12 \mathrm{~h}$ \\
\hline
\end{tabular}

a PM collected on high-volume sampler on quartz fibre filters.

${ }^{b}$ PM collected on low-volume sampler on $47 \mathrm{~mm}$ polycarbonate membrane filter.

c PM collected on a MiniVol sampler on $47 \mathrm{~mm}$ quartz fibre filters.

\section{Experimental}

\subsection{Site description}

Sample collection was carried out in two tunnels located within the SPMA: the Jânio Quadros (JQ) tunnel and the tunnel no. 3 of the Beltway Rodoanel Mário Covas (RA). The campaign at the JQ tunnel took place from 2 to 13 May 2011 whereas the RA tunnel was studied from 6 to 17 July 2011. This work focuses on weekdays (Mon-Fri) measurements only.

The JQ tunnel is located in the southwest portion of the São Paulo city. It is a $1900 \mathrm{~m}$ long, two-lane tunnel with traffic flowing in only one direction. The traffic of HDVs through this tunnel is restricted. Diesel-fuelled vehicles within the JQ tunnel are scarce, limited to urban cargo vehicles (UCVs), vehicles up to $6.3 \mathrm{~m}$ long. The vast majority of the fleet circulating through the JQ tunnel is composed of gasoholfuelled LDVs - and ethanol-powered vehicles and gasoholpowered motorcycles. The tunnel has a slight downhill slope with speed limit of $70 \mathrm{~km} \mathrm{~h}^{-1}$, although average speed may strongly decrease due to traffic congestions. The Rodoanel Mário Covas is a beltway with a radius of approximately $23 \mathrm{~km}$ from the geographical centre of the city downtown area. The RA tunnel is roughly $1700 \mathrm{~m}$ long, four-lane with traffic flowing in only one direction. The tunnel has an important traffic of HDVs, especially heavy trucks transporting large payloads to and from the Santos harbour. Its speed limit is $90 \mathrm{~km} \mathrm{~h}^{-1}$ and $70 \mathrm{~km} \mathrm{~h}^{-1}$ for LDVs and HDVs, respectively. This tunnel features a slight uphill slope.

During the studied period, median values of LDV traffic from 08:00 to 20:00 (local time) were 1806 vehicles $^{-1}$ and 1152 vehicles $\mathrm{h}^{-1}$ in the JQ and RA tunnels, respectively. Diesel-fuelled vehicles, on the other hand, were 4 vehicles $\mathrm{h}^{-1}$ in the JQ tunnel (consisting only of UCVs) and 330 vehicles $\mathrm{h}^{-1}$ (UCVs and large trucks) in the RA tunnels.

\subsection{Instrumentation and analytical methods}

The instrumentation was deployed roughly at the midpoint of both tunnels, located on a trailer from the São Paulo State En- vironmental Regulation Agency (Table 1). Unless stated otherwise, the data reported here corresponds to the fine fraction of the particulate matter, i.e. aerodynamic diameter below $2.5 \mu \mathrm{m}$. The real-time instrumentation sampled air through a $\mathrm{PM}_{2.5}$ cyclone impactor and a silica diffusion drier keeping $\mathrm{RH}<50 \%$. The inlet line consisted of a $2 \mathrm{~m}$ long copper tube with $0.8 \mathrm{~cm}$ inner diameter.

Three samplers were deployed to collect particulate matter on filters: a MiniVol sampler (Airmetrics, $5 \mathrm{Lpm}$ ), a low-volume sampler $(16.6 \mathrm{Lpm})$ and a high-volume sampler (1130 Lpm). The MiniVol filter (Pall Life Science, $47 \mathrm{~mm}$ quartz membrane filter) was used for the quantification of organic and elemental carbon (OCEC analyses). The lowvolume sampler filter $(0.4 \mu \mathrm{m}$ pore size polycarbonate) provided gravimetric and elemental composition whereas the high-volume air sampler filter (quartz fibre) allowed the quantification of PAHs. The MiniVol and low-volume sampler were equipped with $2.5 \mu \mathrm{m}$ impactors. The high-volume sampler was equipped with $10 \mu \mathrm{m}$ impactors.

$\mathrm{OC}$ and EC analysis was performed using thermal-optical transmittance (TOT) (Sunset Laboratory Inc.) (Birch and Cary, 1996). The filters were analysed according to a slightly modified Sunset Labs TOT method with variable time steps lasting between 60 and $200 \mathrm{~s}$ during $\mathrm{OC}$ evolution at temperature plateaus of $310,475,615$, and $870^{\circ} \mathrm{C}$. The temperature profile during EC evolution included $45 \mathrm{~s}$ plateaus at $550,625,700,775$, and $850^{\circ} \mathrm{C}$ with a final hold at $870^{\circ} \mathrm{C}$ for $120 \mathrm{~s}$. Mass concentrations were obtained gravimetrically using an electronic microbalance with a readability of $1 \mu \mathrm{g}$ (Mettler Toledo, model MX5) in a controlled-atmosphere room. Filters were equilibrated for $24 \mathrm{~h}$ prior weighing. Electrostatic charges were controlled with radioactive ${ }^{210} \mathrm{Po}$ sources (Castanho and Artaxo, 2001). Trace element concentrations were determined with an X-ray fluorescence spectrometer (PANalytical, model Epsilon 5). Elements from $\mathrm{Na}$ to $\mathrm{Zn}$ have shown excellent detection limits, e.g. $15.9 \mathrm{ng} \mathrm{cm}^{-2}, 8.6 \mathrm{ng} \mathrm{cm}^{-2}, 2.0 \mathrm{ng} \mathrm{cm}^{-2}$ and $10.8 \mathrm{ng} \mathrm{cm}^{-2}$ for $\mathrm{Al}, \mathrm{P}, \mathrm{Zn}$ and $\mathrm{Pb}$ respectively with 300 s integration time for the light elements and $600 \mathrm{~s}$ for the heavy elements (manuscript in preparation). Details of the technique can be found in Spolnik et al. (2005). PAHs were extracted from 
the high-volume sampler using a Soxhlet apparatus filled with methylene chloride. Quantitative and qualitative analyses were carried out by gas chromatography-mass spectrometry (Varian, model 3800). Thirteen compounds of the 16 major PAH listed by the US EPA (United States Environmental Protection Agency) as priority pollutants were analysed. The observed PAHs, according to their elution order, were phenanthrene (Phe), anthracene (Ant), fluoranthene (Fla), pyrene (Pyr), benzo[a]anthracene $(\mathrm{BaA})$, chrysene $(\mathrm{Chr})$, benzo[b]fluoranthene $(\mathrm{BbF})$, benzo[k]fluoranthene $(\mathrm{BkF})$, benzo[e]pyrene $(\mathrm{BeP})$, benzo[a]pyrene $(\mathrm{BaP})$, indeno[cd]pyrene (InP), dibenzo[a,h]anthracene (DBA) and benzo[ghi]perylene (BPe).

Real-time aerosol light scattering was measured using a nephelometer (TSI Inc., Model 3563) and light absorption by a multi-angle absorption photometer (MAAP, Thermo Scientific, Model 5012). The instruments were coupled in series with a flow rate of $10 \mathrm{Lpm}$ using the MAAP's internal pump downstream of the nephelometer.

The nephelometer measures light scattering coefficients $\left(\sigma_{\mathrm{s}}\right)$ at $450,550,700 \mathrm{~nm}$ wavelengths (Anderson and Ogren, 1998). With the scattering coefficients on three wavelengths the Ångström exponents can be determined. Scattering coefficients were corrected for angular truncation error according to Anderson and Ogren (1998). Instrument calibration was done using particle-free air and carbon dioxide. The nephelometer sampling period was set to $5 \mathrm{~min}$.

The MAAP instrument measures simultaneously the optical attenuation and reflection of particles deposited on a glass fibrous filter from several detection angles to retrieve the aerosol light absorption (Petzold et al., 2005). This unique feature among other commercially available absorption photometers leads MAAP to minimise filter-based method artifacts related to multiple scattering effects, resulting in excellent comparisons with photoacoustic methods (Sheridan et al., 2005; Müller et al., 2011).

The instrument has a sampling period of up to $1 \mathrm{~min}$ and measures light absorption $\left(\sigma_{\mathrm{abs}}\right)$ at $637 \mathrm{~nm}$. Using the Ångström exponents, light scattering was interpolated to the MAAP wavelength, yielding the single-scattering albedo $\left(\omega_{0}\right)$ of the aerosol. The $\omega_{0}$ is a measure of the aerosol particle scattering strength relative to extinction as such:

$\omega_{0}=\frac{\sigma_{\mathrm{s}}}{\sigma_{\mathrm{s}}+\sigma_{\mathrm{abs}}}$

For purely scattering aerosol particles (e.g. ammonium sulphate), $\omega_{0}$ approaches 1.0. In situ observations of dry aerosol $\omega_{0}$ typically show values in the range $0.80-0.98$ for urban aerosols (Anderson et al., 2003), 0.65-0.80 in SPMA (Backman et al., 2012), 0.72-0.88 for fresh biomass burning smoke (Magi, 2003), 0.75-0.95 at an undisturbed forest site in Amazonia (Rizzo et al., 2013) and 0.88-0.99 for coarse mode dominated mineral dust (Anderson et al., 2003).

MAAP evaluates optical absorption by aerosol particles, but the manufacturer opted to report equivalent black carbon
(EBC) concentrations instead, assuming a constant massspecific absorption cross section (MAC) of $6.6 \mathrm{~m}^{2} \mathrm{~g}^{-1}$. The relationship between $\sigma_{\mathrm{abs}}$ and EBC mass concentration is

$\mathrm{EBC}=\frac{\sigma_{\mathrm{abs}}}{\mathrm{MAC}}$

This generalisation does not take into account variations of MAC as a function of particle physical and chemical properties, nor changes in particle morphology upon deposition on the filter substrate. For the analysis of particle optical properties, EBC concentration was converted back to absorption coefficient, which is the actual MAAP measurement, through Eq. (2). Further discussion of the instrument corrections and site-specific MAC values is given on Sect. 3.3.1.

Aerosol size distribution at the range of $10-430 \mathrm{~nm}$ has been measured using a SMPS (Scanning Mobility Particle Sizer, TSI) composed of an electrostatic classifier (TSI, model 3080) along with a CPC (Condensational Particle Counter, TSI, model 3772).

\subsubsection{Correction procedure for real-time EBC measurements}

The MAAP, designed to estimate real-time EBC mass concentration, was deployed in the JQ and RA tunnels. However, due to considerably high EBC loadings, the instrument did not function properly. Whereas the JQ tunnel data could be corrected (independent EC measurement $\sim 10-15 \mu \mathrm{g} \mathrm{m}^{-3}$ ), the instrument within the RA tunnel saturated and unfortunately did not provide reliable data (independent EC measurement $\sim 120 \mathrm{\mu g} \mathrm{m}^{-3}$ ). The JQ tunnel data have been corrected due to an artefact found in the instrument firmware that affects the instrument accuracy in environments characterised by fast changes in the light attenuation, i.e. a high rate of EBC deposition on the filter (Hyvärinen et al., 2013). This accumulation rate parameter is defined as

$\Delta \mathrm{EBC}=\mathrm{EBC} \times Q$

where $Q$ is the flow rate of the instrument. The artefact affects system accuracy for $\triangle \mathrm{EBC} \geq 0.04 \mu \mathrm{g} \mathrm{min}^{-1}$, roughly $\mathrm{EBC} \geq 3 \mu \mathrm{g} \mathrm{m}^{-3}$ for usual flow of $1 \mathrm{~m}^{3} \mathrm{~h}^{-1}$.

Such artefact caused a weaker than anticipated light attenuation after a spot change. Applying the correction procedure described by Hyvärinen et al. (2013) corrected the artefact for most of the data. However, measurements made shortly after the filter spot change (light attenuation above $80 \%$ of reference) had to be removed due to unrealistic values. The uncorrected and corrected data are shown on Fig. 2.

\section{Results and discussion}

During the study period, over 930000 vehicles circulated through both tunnels. In the JQ tunnel, cameras registered the traffic, allowing LDVs, UCVs and motorcycles to be 


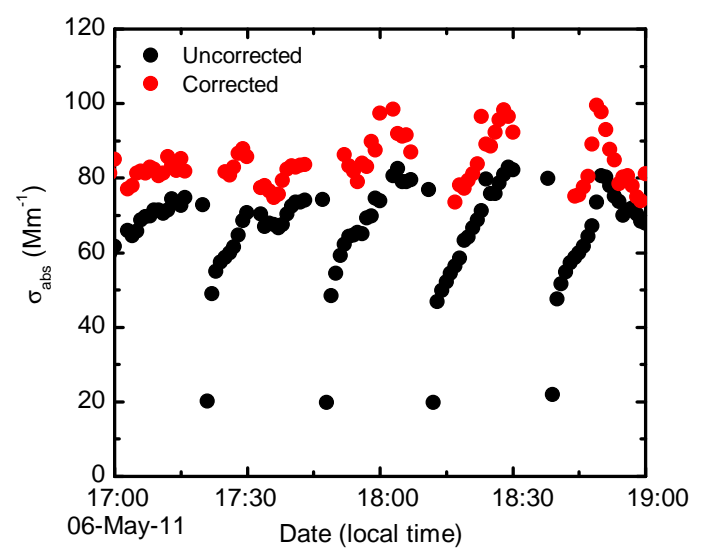

Fig. 2. Detailed view of the uncorrected and correct MAAP data from the JQ tunnel. Correction procedure performed according to Hyvärinen et al. (2013). Furthermore, measurements performed with light attenuation above $80 \%$ of reference (i.e. shortly after filter spot change) were removed.

counted a posteriori. Given that the vehicle velocity was not measured in the JQ tunnel, traffic congestions events were flagged based on the driving patterns. In the RA tunnel, categorised traffic volumes (LDVs, HDVs) and speeds were measured using ground sensors. The LDVs were defined to be those with a wheel pair distance smaller than $5.5 \mathrm{~m}$ and vice versa for the HDVs (generally this translates to LDVs being lighter than $3.5 \mathrm{t}$ ). Figures 3 and 4 show the weekday traffic diurnal variation on the JQ and RA tunnel, respectively.

Both tunnels are considered not to be strongly influenced by background aerosol population. Whereas the RA tunnel is located in the outskirts of São Paulo, without important local sources of aerosol, the JQ tunnel does not possess an active ventilation mechanism. As such, the air exchange is essentially driven by the motion of traffic, resulting in strong concentration gradients between inside and outside the tunnel. Carbon monoxide (CO), an important tracer for vehicular combustion, has been observed during the filter collection periods to be on average 4.6 times higher inside the tunnel $(5.4 \pm 1.0 \mathrm{ppmv})$ relative to outside $(1.2 \pm 0.3 \mathrm{ppmv})$. Furthermore, due to traffic restrictions of heavy-duty vehicles in the sampling area, the atmosphere outside the JQ tunnel is largely impacted by LDVs, i.e. the same source profile as inside the tunnel. As such, subtraction of background (outside) signatures would certainly lead to mischaracterisation of LDVs emission. In the following sections, particulate matter chemical composition, size distribution and optical properties are presented.

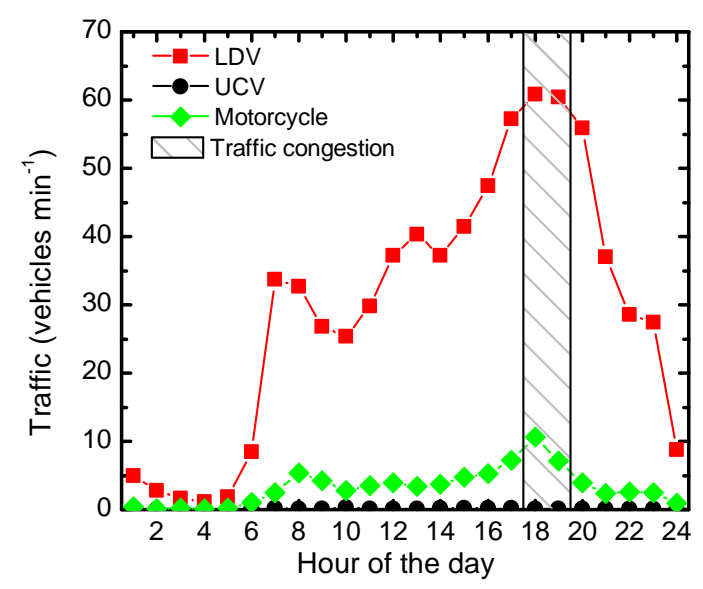

Fig. 3. Median values for vehicular traffic in the JQ tunnel. Hour of the day in local time. The hashed area indicates that at least $50 \%$ of the days' traffic congestions were observed during those hours of the day. Urban cargo vehicles (UCVs), limited to a length of $6.3 \mathrm{~m}$, are the only diesel-fuelled vehicles allowed to use the JQ tunnel. Whereas most of the LDVs are flexible fuel vehicles, motorcycles are limited to gasohol.

\subsection{The particulate matter composition}

\subsubsection{OC, EC and trace elements}

The $\mathrm{PM}_{2.5}$ mass concentration, OC, EC and elemental composition are shown in Table 2. The average $\mathrm{PM}_{2.5}$ concentration in the RA and JQ tunnel is $233 \mu \mathrm{g} \mathrm{m}^{-3}$ and $52 \mu \mathrm{g} \mathrm{m}^{-3}$, respectively. Given the comparable number of LDVs circulating through both tunnels, the high $\mathrm{PM}_{2.5}$ concentration found in the RA tunnel (over four times higher than in the JQ tunnel) indicates the large contribution of HDVs to the directly emitted fine particulate matter.

As previously discussed, a strong abundance of $\mathrm{CO}$ inside the tunnel relative to the outside has been observed due to poor air exchange. Furthermore, other measurements corroborate the dominance of aerosols emitted from LDVs traversing the tunnel relative to outside contamination. EBC, for example, has been previously reported in São Paulo with daily averages ranging from $1.1 \mu \mathrm{g} \mathrm{m}^{-3}$ to $2.7 \mu \mathrm{g} \mathrm{m}^{-3}$ (Backman et al., 2012). Such a concentration range, impacted by both HDVs and LDVs, is considerably lower than observed inside the JQ tunnel $\left(8.7 \pm 1.4 \mu \mathrm{g} \mathrm{m}^{-3}\right)$. As such, it is clear that the studied aerosol population is strongly dominated by local emissions rather than ambient contamination.

The average OC: EC ratio for samples collected in the JQ tunnel was $1.59 \pm 0.09$. Previous tunnel measurements focusing on gasoline-fuelled LDVs reported an OC: EC ratio in the fine particulate matter of 2.4 (Landis et al., 2007), a ratio $50 \%$ higher than observed in the JQ tunnel. Furthermore, the OC: EC ratio obtained in the JQ tunnel falls close to the lower bound of the literature values for LDVs (OC : EC ratio $>1$ ), including a broad range of fuels (gasoline and 
Table 2. Species concentrations in the studied tunnels. $\mathrm{PM}_{2.5}, \mathrm{OC}$, and $\mathrm{EC}$ are given in $\mu \mathrm{gm}^{-3}$. Trace elements are given in ng ${ }^{-3}$. $N$ indicates the number of collected filters where a given parameter has been detected.

\begin{tabular}{|c|c|c|c|c|c|c|c|c|c|c|}
\hline \multirow[t]{2}{*}{ Species } & \multicolumn{5}{|c|}{ JQ } & \multicolumn{5}{|c|}{ RA } \\
\hline & Mean & $\sigma^{\mathrm{a}}$ & Min & Max & $N$ & Mean & $\sigma^{\mathrm{a}}$ & Min & $\operatorname{Max}$ & $N$ \\
\hline $\mathrm{PM}_{2.5}$ & 52.3 & 2.9 & 48.9 & 58.3 & 6 & 232.7 & 20.6 & 201.9 & 281.7 & 13 \\
\hline $\mathrm{OC}$ & 13.8 & 2.3 & 10.5 & 17.6 & 6 & 59.7 & 14.4 & 32.5 & 98.1 & 13 \\
\hline $\mathrm{EC}$ & 8.7 & 1.4 & 6.4 & 10.8 & 6 & 121.6 & 17.4 & 76.0 & 149.4 & 13 \\
\hline \multicolumn{11}{|c|}{$\mathrm{TE}\left(\mathrm{ngm}^{-3}\right)$} \\
\hline $\mathrm{Na}$ & 194.2 & 64.1 & 130.4 & 320.8 & 6 & 199.1 & 97.6 & 68.4 & 476.4 & 13 \\
\hline $\mathrm{Mg}$ & 86.1 & 27.8 & 44.2 & 135.3 & 6 & 110.0 & 33.2 & 61.3 & 172.4 & 13 \\
\hline $\mathrm{Al}$ & 218.0 & 35.2 & 177.2 & 269.6 & 6 & 405.0 & 120.0 & 210.4 & 572.8 & 13 \\
\hline $\mathrm{Si}$ & 462.6 & 80.4 & 347.0 & 563.4 & 6 & 998.7 & 217.8 & 565.5 & 1262.7 & 13 \\
\hline $\mathrm{P}$ & 67.2 & 15.2 & 53.7 & 96.1 & 6 & 262.9 & 28.4 & 228.0 & 316.4 & 13 \\
\hline S & 1253.4 & 195.6 & 996.5 & 1590.3 & 6 & 3657.2 & 781.6 & 2714.6 & 5356.9 & 13 \\
\hline $\mathrm{Cl}$ & 44.3 & 14.7 & 15.3 & 58.5 & 6 & 78.8 & 40.0 & 33.1 & 190.4 & 13 \\
\hline K & 214.6 & 92.9 & 141.1 & 408.4 & 6 & 720.4 & 402.4 & 218.5 & 1797.2 & 13 \\
\hline $\mathrm{Ca}$ & 324.3 & 26.2 & 278.2 & 364.3 & 6 & 523.3 & 94.9 & 430.5 & 822.6 & 13 \\
\hline $\mathrm{Ti}$ & 143.4 & 14.0 & 118.9 & 164.3 & 6 & 114.7 & 20.9 & 70.0 & 162.7 & 13 \\
\hline V & 12.9 & 3.3 & 7.5 & 17.5 & 6 & 11.3 & 4.3 & 3.8 & 20.5 & 13 \\
\hline $\mathrm{Cr}$ & 31.8 & 4.8 & 25.9 & 40.6 & 6 & 11.5 & 5.0 & 3.9 & 20.8 & 13 \\
\hline $\mathrm{Mn}$ & 69.1 & 14.5 & 44.5 & 89.6 & 6 & 36.7 & 8.3 & 17.8 & 54.5 & 13 \\
\hline $\mathrm{Fe}$ & 6304.9 & 574.2 & 5117.5 & 6888.7 & 6 & 1769.9 & 192.9 & 1450.2 & 2097.1 & 13 \\
\hline $\mathrm{Ni}$ & 1.8 & 2.0 & 0.3 & 5.7 & 5 & 2.2 & 1.7 & 0.1 & 6.3 & 11 \\
\hline $\mathrm{Cu}$ & 315.9 & 26.8 & 282.8 & 349.6 & 6 & 39.2 & 13.1 & 25.2 & 79.4 & 13 \\
\hline $\mathrm{Zn}$ & 179.0 & 65.0 & 96.8 & 287.6 & 6 & 287.3 & 74.5 & 203.7 & 499.8 & 13 \\
\hline As & 1.2 & 0.8 & 0.5 & 2.0 & 2 & 3.2 & 2.4 & 0.2 & 6.3 & 4 \\
\hline $\mathrm{Se}$ & 7.7 & 4.5 & 2.9 & 15.5 & 6 & 8.9 & 8.4 & 1.1 & 29.8 & 10 \\
\hline $\mathrm{Br}$ & 1.8 & 1.1 & 0.5 & 3.0 & 3 & 12.6 & 6.1 & 2.9 & 23.5 & 13 \\
\hline $\mathrm{Rb}$ & \multicolumn{5}{|c|}{$\mathrm{ND}^{\mathrm{b}}$} & 1.1 & 1.0 & 0.1 & 2.5 & 7 \\
\hline $\mathrm{Sr}$ & \multicolumn{5}{|c|}{$\mathrm{ND}^{\mathrm{b}}$} & 11.8 & 9.7 & 2.6 & 25.2 & 3 \\
\hline $\mathrm{Cd}$ & 19.7 & 8.9 & 10.7 & 28.6 & 2 & 32.1 & 28.3 & 7.8 & 88.5 & 6 \\
\hline $\mathrm{Sb}$ & 38.4 & 13.4 & 20.8 & 54.2 & 4 & 14.3 & 5.3 & 6.2 & 19.3 & 5 \\
\hline $\mathrm{Pb}$ & 18.1 & 5.6 & 11.5 & 27.6 & 5 & 25.2 & 17.4 & 4.6 & 65.6 & 13 \\
\hline
\end{tabular}

a Standard deviation.

b Not detected.

diesel with different degrees of sulphur content) and aerosol size cuts $(2.5 \mu \mathrm{m}$ and $10 \mu \mathrm{m})($ Cadle et al., 1999; Gillies and Gertler, 2000; Allen et al., 2001; Grieshop et al., 2006; Landis et al., 2007; Handler et al., 2008; Ning et al., 2008). Such considerably low OC: EC ratio in the JQ tunnel indicates an important contribution of EC in the Brazilian LDV fleet despite the high biofuel usage. The OC:EC ratio obtained from the RA tunnel was $0.49 \pm 0.12$, a value compatible with several tunnel studies of diesel-fuelled HDVs reporting OC: EC ratio close to 0.5 (Cadle et al., 1999; Allen et al., 2001; Grieshop et al., 2006; Landis et al., 2007; Handler et al., 2008; He et al., 2008; Zhang et al., 2009).

The most abundant trace elements in the JQ tunnel were $\mathrm{Fe}, \mathrm{S}, \mathrm{Si}, \mathrm{Cu}$ and $\mathrm{Ca}$. The abundance of such trace elements, with the exception of $\mathrm{Cu}$, are in good agreement with gasohol- and ethanol-fuelled vehicles measurements in dynamometers (Ferreira da Silva et al., 2010) and in previous tunnel studies (Sánchez-Ccoyllo et al., 2009). The high abun- dance of $\mathrm{Cu}$, linked to brake lining, is mainly attributed to a stop-and-go driving pattern in the JQ tunnel due to traffic congestions. Given the fact that many brake linings use $\mathrm{Sb}_{2} \mathrm{~S}_{3}$ up to at least $5-7 \%$ by weight (Garg et al., 2000), Sternbeck et al. (2002) proposed a diagnostic ratio of $\mathrm{Cu}: \mathrm{Sb}$ $4.6 \pm 2.3$ (both $2.5 \mu \mathrm{m}$ and $10 \mu \mathrm{m}$ size cut) to identify such source impact on ambient air. Here, the ratio for the JQ tunnel is considerably higher (8.2). It has been previously suggested that ethanol processing of copper tanks enhances gasohol-fuelled vehicles $\mathrm{Cu}$ emission factors (Castanho and Artaxo, 2001; Sánchez-Ccoyllo et al., 2009), thus indicating that higher $\mathrm{Cu}: \mathrm{Sb}$ ratios than expected are only due to brake lining. Whether such difference is due to the suggested ethanol usage (and therefore could be used as a marker) or is due to a different brake lining composition cannot be determined from this study and demands further investigation.

The most abundant elements found in the RA tunnel were $\mathrm{S}, \mathrm{Fe}$ and $\mathrm{Si}$, respectively. Such results are in good agreement 


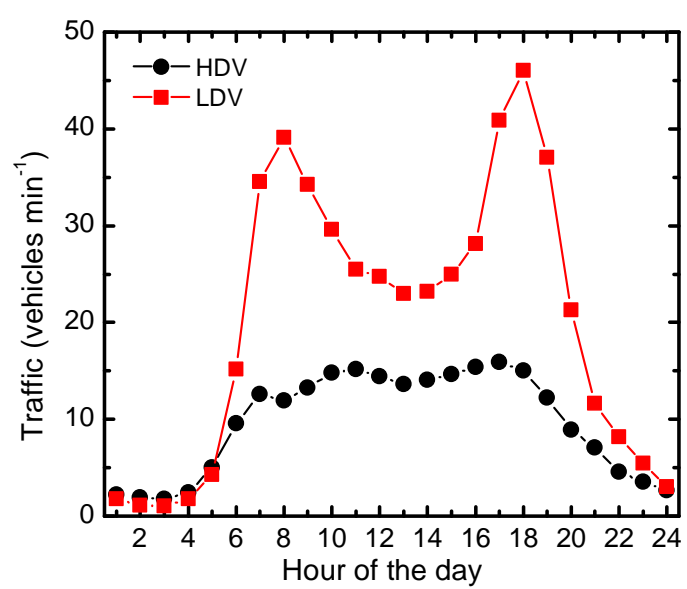

Fig. 4. Median values for vehicular traffic in the RA tunnel. Hour of the day in local time. No traffic congestions were observed in the RA tunnel during the studied period. The majority of HDVs in this tunnel are large trucks. LDVs are mostly flexible fuel vehicles. Motorcycles were not apportioned in this tunnel; however, due to its location (outside city limits), very few are expected to be found.

with other studies focusing on HDV diesel emission in tunnels (Landis et al., 2007) and near a freeway (Ntziachristos et al., 2007). Ca, associated with lube oil additives in diesel engines (Matti Maricq, 2007), has been one of the most abundant elements in HDV diesel emission in the US (Landis et al., 2007; Ntziachristos et al., 2007). However, Ca is not among the most abundant in the RA tunnel. K, however, is the fourth most abundant element in the RA tunnel. Previous receptor modelling studies in the SPMA have found significant amounts of $\mathrm{K}$ in profiles linked to LDV and HDV emissions, especially with the latter (Castanho and Artaxo, 2001; Andrade et al., 2012). Given that $\mathrm{K}$ is found in vegetation, high levels of this element from vehicular emissions could be due to biofuel usage (Andrade et al., 2012).

In an effort to better constrain the trace elements from vehicular sources, the enrichment factor (EF) relative to the upper continental crust (UCC) has been calculated (Dodd et al., 1991):

$\mathrm{EF}=\frac{\left(C_{\mathrm{x}} / C_{\mathrm{ref}}\right)_{\mathrm{PM}}}{\left(C_{\mathrm{x}} / C_{\mathrm{ref}}\right)_{\mathrm{UCC}}}$

where $C_{\mathrm{x}}$ and $C_{\text {ref }}$ are the concentrations of element $\mathrm{X}$ and a reference element, respectively. The elemental concentration ratio of ambient PM to that of the UCC (Taylor and McLennan, 1995) yields useful information as to what extent metals are enriched in particle samples due to anthropogenic processes. If the EF of an element is close to 1, its origin is crustal. Given the expected differences between crustal composition found in the SPMA tunnels and the UCC, elements yielding EF below 10 were assumed to be crustal. From 10 to 60 , the elements are assigned to a mixed contribution between vehicular and crustal origins. The reference element
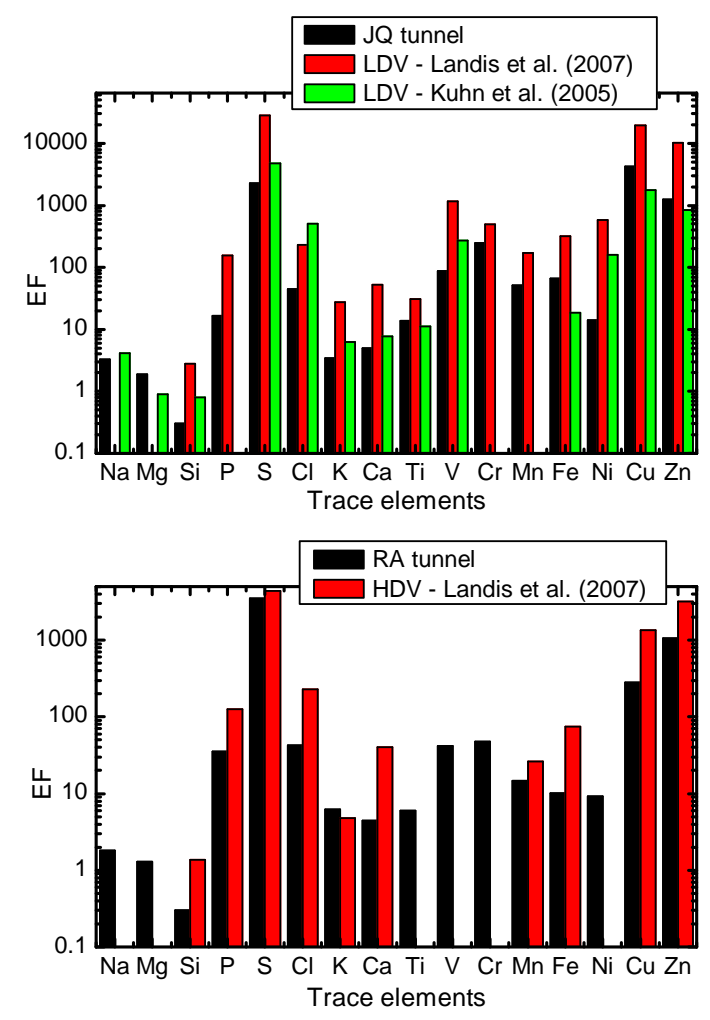

Fig. 5. Enrichment factor (EF) analysis relative to the UCC composition using $\mathrm{Al}$ as reference material. Top: results of the JQ tunnel and previous works on gasoline-fuelled LDVs near a freeway (Kuhn et al., 2005) and in tunnel (Landis et al., 2007). Bottom: EF results from the RA tunnel and results for diesel-fuelled HDVs in tunnels (Landis et al., 2007).

is chosen according to its consistence and uniform presence in UCC. In this study, $\mathrm{Al}$ was used as the reference element. Figure 5 shows the EF analysis results for JQ and RA tunnels, along with results from previous US works near a light-duty vehicle freeway (Kuhn et al., 2005) and in US tunnel measurements (Landis et al., 2007).

Results from the EF analysis of the JQ and RA tunnels show similar trends as observed in previous studies. The EF from $\mathrm{S}$ is smaller in the JQ tunnel than measured by Kuhn et al. (2005) and Landis et al. (2007), however roughly in the same proportion as many other elements. The elements apportioned to crustal source in the JQ tunnel are $\mathrm{Na}, \mathrm{Mg}$, $\mathrm{Al}, \mathrm{Si}, \mathrm{K}$ and $\mathrm{Ca}$. Elements with both vehicular and crustal sources are $\mathrm{P}, \mathrm{Cl}, \mathrm{Ti}, \mathrm{Mn}, \mathrm{Fe}$ and $\mathrm{Ni}$. The relatively low $\mathrm{EF}$ of $\mathrm{K}$ in the JQ tunnel, close to $\mathrm{Ca}$ and $\mathrm{Na}$, indicates that this element cannot be used as a marker for ethanol usage.

In the RA tunnel, all elements are consistently below the EF calculated from Landis et al. (2007), except K. This suggests indeed a higher emission of $\mathrm{K}$ from Brazilian HDVs, as in the US. Nevertheless, the EF of K is quite low (6), indicating, according to the analysis described here, a major crustal origin with negligible vehicular contribution. If the higher 
Table 3. Particle phase PAH concentration ranges in the JQ and RA tunnels.

\begin{tabular}{lcc}
\hline $\begin{array}{l}\text { PAH } \\
\left(\mathrm{ng} \mathrm{m}^{-3}\right)\end{array}$ & $\begin{array}{c}\text { JQ } \\
(n=5)\end{array}$ & $\begin{array}{c}\text { RA } \\
(n=11)\end{array}$ \\
\hline Acenaphtylene & $0.29-11.81$ & $0.53-3.99$ \\
Fluorene & $0.41-16.98$ & $0.97-1.67$ \\
Phenanthrene & $2.16-17.3$ & $5.41-8.21$ \\
Anthracene & $0.68-9.98$ & $0.67-1.64$ \\
Fluoranthene & $0.13-1.56$ & $0.24-1.25$ \\
Pyrene & $0.93-11.52$ & $0.32-3.97$ \\
Benzo[a]anthracene & $1.95-8.14$ & $4.90-6.35$ \\
Chrysene & $0.82-4.39$ & $0.28-5.05$ \\
Benzo[b]fluoranthene & $0.89-13.93$ & $2.15-9.98$ \\
Benzo[k]fluoranthene & $0.78-8.86$ & $2.07-3.43$ \\
Benzo[e]pyrene & $0.87-3.60$ & $2.34-3.97$ \\
Benzo[a]pyrene & $0.90-6.73$ & $2.28-2.87$ \\
Indeno[cd]pyrene & $0.77-13.43$ & $1.93-5.50$ \\
Dibenzo[a,h]anthracene & $1.54-6.93$ & $3.85-7.97$ \\
Benzo[ghi]perylene & $0.30-16.26$ & $0.97-3.57$ \\
\hline
\end{tabular}

abundance of $\mathrm{K}$ is indeed linked to biodiesel usage and its fraction in diesel continues to raise, this element seems to be a promising candidate for a marker of biodiesel-fuelled HDVs. In the RA tunnel, the elements $\mathrm{Na}, \mathrm{Mg}, \mathrm{Al}, \mathrm{Si}, \mathrm{K}, \mathrm{Ca}$, $\mathrm{Ti}$ and $\mathrm{Ni}$ were assigned to mostly crustal origin whereas elements with both vehicular and crustal sources were $\mathrm{P}, \mathrm{Cl}, \mathrm{V}$, $\mathrm{Cr}, \mathrm{Mn}$ and $\mathrm{Fe}$.

\subsubsection{Polycyclic aromatic hydrocarbons}

PAHs in the atmospheric samples are the organic compounds that present the greatest concern for human health. They are stable forms of hydrocarbons and are mostly formed during the incomplete combustion and pyrolysis of fossil fuels or wood and from release of petroleum products (Manahan, 2005). The emission of PAHs is a function of engine type, load and age, fuel type and quality, PAH accumulation in lubricant oil, lubricant oil combustion and driving mode (Ravindra et al., 2008). PAHs in the environment are present in both particulate and gaseous phases. Their distribution between both phases is dependent on molecular weight, ambient temperature, their concentration and particle composition (Guarieiro et al., 2014). In the present study only particle phase concentrations are reported, which for lower molecular weight PAHs total PAH concentrations are certainly substantially underestimated but for high molecular weight PAHs total PAH concentrations are close to total concentrations, as observed in other emission studies (Ho et al., 2009).

Table 3 summarises the PAH concentrations in the JQ and RA tunnel in the size ranges up to $10 \mu \mathrm{m}$. The higher size-cut of high volume sampler might induce a bias when comparing to $\mathrm{PM}_{2.5}$ samples, although PAHs are mostly found in the fine aerosol fraction. Oliveira et al. (2011), for example, have reported in tunnel measurements that over $98 \%$ of the PAH mass is found below $2.5 \mu \mathrm{m}$ size range. As such, to assume that the observed ambient concentration is found in the fine aerosol size range induces an error that is largely surpassed by quantification uncertainties.

The sum of PAH concentrations for the RA tunnel was $56 \pm 5 \mathrm{ng} \mathrm{m}^{-3}$ and for the JQ tunnel was $45 \pm 9 \mathrm{ng} \mathrm{m}^{-3}$. For JQ tunnel, a light vehicles tunnel, PHE (16\%), BaA (13\%) and $\mathrm{BbF}$ and DBA (11\%) were the most abundant detected PAHs. For RA samples, there were differences between the dominant compounds, yet, on average, $\mathrm{BaA}(12 \%)$ and DBA and $\mathrm{BPe}(11 \%)$ were the most abundant.

Dobbins et al. (2006) showed that 0.2 and $1.0 \mathrm{wt} \%$ of the two to four ring PAHs survive the combustion process and compose a significant concentration of the mutagenic compounds in particulate emissions. Given that a substantial fraction of such PAHs are to be found in the gas-phase, large uncertainties are usually associated with filter-based measurement of such compounds. Nevertheless, in the JQ tunnel, 3 and 4 rings particle-phase PAHs accounted for 24 to $66 \%$ of those identified, while in RA they accounted for from 37 to $77 \%$.

Since few studies have been performed in Brazilian tunnels, a comparison is done with the literature, despite the different fuels used. The literature shows that ratios between some PAHs can indicate the most important contributions of different vehicles (light and heavy duty cars). Rogge et al. (1993b) attributed the ratio of $\mathrm{InP} /(\mathrm{InP}+\mathrm{BPe})$ in the range $0.35-0.70$ to diesel emissions and $\mathrm{BaA} / \mathrm{Chr}$ ratios over 0.7 indicated gasoline-burning contributions. The results obtained here show a $\mathrm{InP} /(\mathrm{InP}+\mathrm{BPe})$ ratio in the RA tunnel of $0.24-0.91$ and in the JQ tunnel values of $0.7-1.5$. The $\mathrm{BaA} / \mathrm{Chr}$ ratio in the RA tunnel ranged from $0.8-3.3$ and $1.0-12.4$ in the JQ tunnel. A previous study was performed in 2001 in the JQ tunnel (Vasconcellos et al., 2003) and in the Maria Maluf (MM) tunnel, with similar profile to the RA tunnel. The study reported $\mathrm{InP} /(\mathrm{InP}+\mathrm{BPe})$ ratios of 0.55 (JQ tunnel) and 0.36 (MM tunnel), linked to LDVs and HDVs, respectively. The $\mathrm{BaA} / \mathrm{Chr}$ ratio ranged from 0.48 (JQ tunnel) to 0.79 (MM tunnel).

$\mathrm{BaP}$, the most studied PAH due to its carcinogenic potential, was found to range from 0.9 to $6.7 \mathrm{ng} \mathrm{m}^{-3}(0.02-0.1 \%$ o of $\mathrm{PM}_{2.5}$ ) in the JQ tunnel whereas in the RA tunnel $\mathrm{BaP}$ ranged from 0.9 to $4.9 \mathrm{ng} \mathrm{m}^{-3}\left(0.004-0.02 \%\right.$ of $\left.\mathrm{PM}_{2.5}\right)$, indicating an important relative contribution of LDVs emissions to atmospheric BaP. Such results agree with the literature values of $\mathrm{BaP}$ mass fraction of $\mathrm{PM}_{2.5}$ of $0.1 \%$ o for catalyst equipped gasoline-powered LDVs and $0.003 \%$ for diesel-powered HDVs (Rogge et al., 1993b).

\subsubsection{Chemical mass balance}

Using the information depicted in Table 2, a mass closure study has been performed. The mass contribution of the trace elements has been calculated according to their common oxides (Kleeman et al., 2000). The sulphate sampled in the 


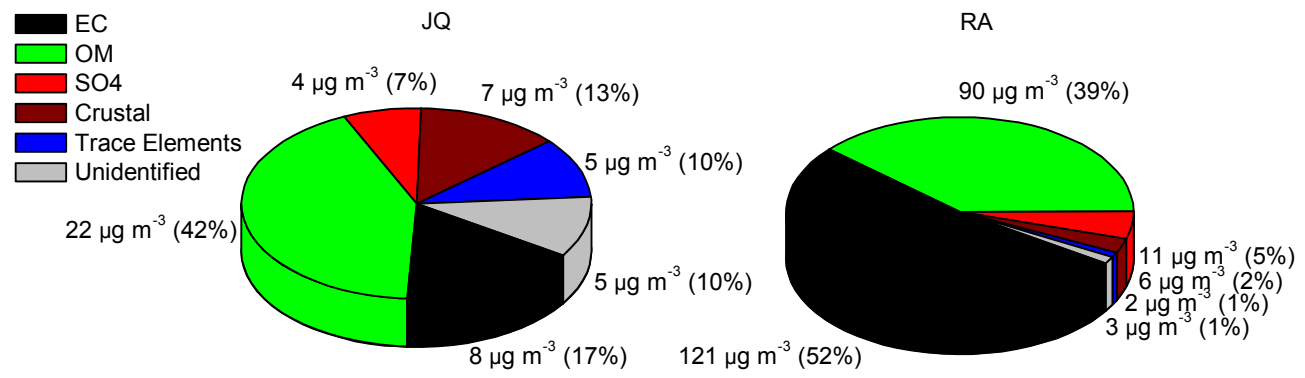

Fig. 6. Chemical mass balance in the JQ (left) and in the RA (right) tunnels. The crustal mass (brown fractions) was calculated by combining the mass of the elements uniquely apportioned to crustal sources and half of the mass (as approximation) of elements apportioned to both vehicular and crustal sources (Sect. 3.1.1). Sulphate mass (red fractions) was estimated from $\mathrm{S}$ using a factor of 3 (corresponding to the atomic mass of $\mathrm{S}$ relative to $\mathrm{SO}_{4}{ }^{2-}$ mass). The other elements, excluding $\mathrm{S}$ and crustal, are grouped as trace elements (blue fractions). The organic mass (OM) (green fractions) is estimated from OC measurements using a ratio of 1.6 for the JQ tunnel and 1.5 for the RA tunnel. The difference between $\mathrm{PM}_{2.5}$ mass determined gravimetrically and the sum of identified compounds are labelled as unidentified compounds (grey fractions).

tunnels was not considered to be neutralised with ammonia in the form $\left[\mathrm{NH}_{4}\right]_{2} \mathrm{SO}_{4}$ due to expected excess of sulphur relative to ammonia in vehicular emissions. As such, its mass was estimated from $\mathrm{S}$ using a factor of 3 . The mass contribution from crustal elements was calculated according to the source apportionment based on the results of the EF analysis, discussed in Sect. 3.1.1. The crustal mass was calculated by combining the mass of the elements uniquely apportioned to crustal sources and half of the mass (as approximation) of elements apportioned to both vehicular and crustal sources. The rest of the mass relative to trace elements, except sulphate and crustal, were combined and are listed as TE $\left(\mathrm{ng} \mathrm{m}^{-3}\right)$ (trace elements).

The organic mass $(\mathrm{OM})$ can be estimated from $\mathrm{OC}$ measurements through a multiplying factor dependent on the aerosol source and its level of atmospheric processing. Literature values of the OC: OM ratio in tunnel/freeway measurements impacted by gasoline- and/or diesel-fuelled vehicles emissions ranges from 1.2 (Allen et al., 2001; Kristensson et al., 2004; Grieshop et al., 2006; Huang et al., 2006; Landis et al., 2007) to 1.4 (Geller et al., 2005; Lipsky and Robinson, 2006; He et al., 2008). Such ratio reflects the composition of the organic aerosol itself, i.e. the contribution of $\mathrm{H}, \mathrm{O}$, S, N (not detected using the thermal-optical measurement) relative to the number of carbon atoms. Due to considerable fraction of ethanol usage (and to a lesser extent, biodiesel) in Brazil, the organic aerosol associated with tailpipe emissions of the Brazilian fleet is expected to be more oxygenated than elsewhere, i.e. more oxygen $(\mathrm{amu}=16)$ and less hydrogen $(\mathrm{amu}=1)$ atoms per carbon. The OC : OM ratio applied here has been chosen to reflect the higher oxygen content of the fuel, as well as taking into account the difference between $\mathrm{PM}_{2.5}$ mass determined gravimetrically and the sum of identified compounds (labelled "Unidentified" in Fig. 6). As such, an OC: OM ratio of 1.6 was chosen for the JQ tunnel and 1.5 for the RA tunnel. To our knowledge, no direct measurement of $\mathrm{OC}$ : OM ratio has been previously reported on such emissions.

The results from the chemical mass balance are shown on Fig. 6. The most abundant components in the JQ tunnel are OM (42\%), followed by EC (17\%) and crustal (13\%). In the RA tunnel, on the other hand, the impact of EC emissions from HDVs results in a large abundance (52\%), followed by OM (39\%). Sulphate ranged from $7 \%$ in the JQ tunnel to $5 \%$ in the RA tunnel, indicating that a significant fraction of sulphur is either emitted directly from the tailpipes or quickly oxidised to the particle phase. Nonetheless, its contribution to $\mathrm{PM}_{2.5}$ mass balance is considerably smaller than that found in ambient samples in the SPMA $(\sim 20 \%)$ (Ynoue and Andrade, 2004; Castanho and Artaxo, 2001; Andrade et al., 2012). Trace elements associated with vehicular sources account for $10 \%$ and $1 \%$ in the JQ and RA tunnels, respectively. In similar proportion, the unidentified mass in the JQ tunnel accounted for $10 \%$ of the $\mathrm{PM}_{2.5}$ and $1 \%$ in the RA tunnel. The difference in unapportioned mass is probably due to nitrate and ions, not analysed here, or water retained in the filter.

The OC: OM ratio is usually a large source of uncertainty in ambient chemical mass balance analysis. Through the difference between the sum of the identified compounds and the filter mass, the upper limit of the OM : OC ratio in each tunnel can be estimated (Bae et al., 2006). The OM: OC ratios obtained using this method are upper limits instead of an estimate, given that nitrate and ions were not included in the chemical mass balance. In the RA tunnel, heavily impacted by diesel emissions, the OM : OC upper limit is 1.6 , whereas in the JQ tunnel an OM: OC ratio upper limit of 2.0 was obtained.

\subsection{Particle size distribution}

Particle size distribution was measured in the JQ tunnel from 2 to 6 May 2011, roughly half of the time of the campaign. 


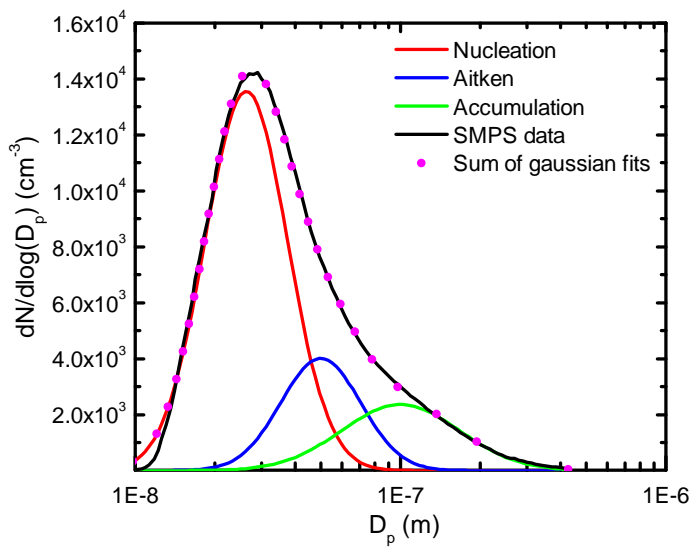

Fig. 7. Average aerosol size distribution in the JQ tunnel. Particle size distribution was measured from 2 to 6 May 2011. The average particle number concentration was $73000 \mathrm{~cm}^{-3}$ with an average diameter of $48.4 \mathrm{~nm}$.

In the RA tunnel, the SMPS sampled in total for about $16 \mathrm{~h}$, on the 7, 12 and 13 July 2011, mostly during daytime. The average particle count yielded $73000 \mathrm{~cm}^{-3}$ in the JQ tunnel and $366000 \mathrm{~cm}^{-3}$ in the RA tunnel, with an average diameter of $48.4 \mathrm{~nm}$ in the former and $38.7 \mathrm{~nm}$ in the latter.

The submicron aerosol size distribution data have been fitted in three Gaussian modes, assessing the contribution of nucleation, Aitken and accumulation modes. The average size number distribution is shown in Figs. 7 and 8. As such, Gaussian mode fitting show very little contribution in the accumulation mode in the RA, whereas its peak height in the JQ tunnel was roughly $60 \%$ in the Aitken mode. Nonetheless, the vast majority of the ultra fine particles (UFP) were found in the nucleation mode for both tunnels. Previous tunnel studies show $80-90 \%$ of submicrometer particles with diameters less than $40 \mathrm{~nm}$ (Abu-Allaban et al., 2002; Geller et al., 2005). Their results, similar to those obtained here, indicate a small impact of biofuel on the aerosol size distribution.

\subsection{Optical properties}

\subsubsection{Mass absorption coefficient}

The mass-specific absorption cross section (MAC) is an essential parameter used in filter-based EBC measurements that rely solely on optical methods. As described earlier, the MAC allows the conversion of light attenuation into EBC concentration. The MAAP instrument uses a constant value of $6.6 \mathrm{~m}^{2} \mathrm{~g}^{-1}$, which is recommended by the manufacturer. However, this value has been the subject of strong debate (Pan et al., 2011; Pandolfi et al., 2011; Healy et al., 2012; Crippa et al., 2013). Here, the aerosol light absorption measured using the MAAP in the JQ tunnel was compared with EC determined from the collected filters by means of a Sunset analyser.

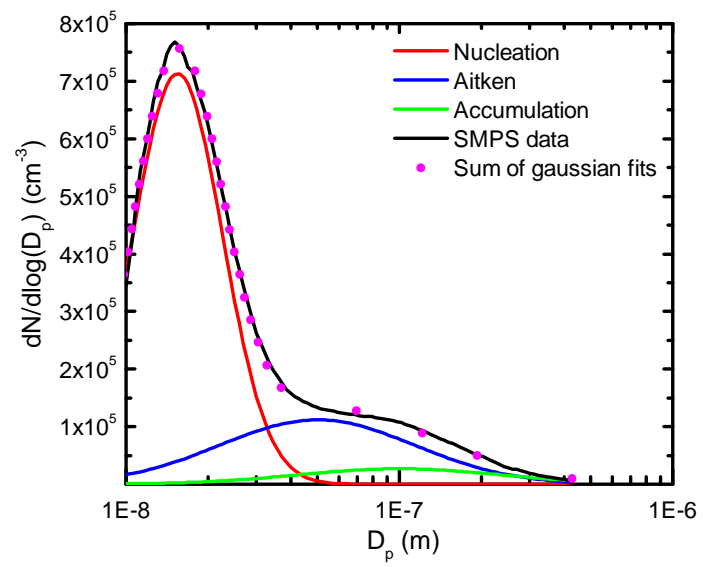

Fig. 8. Average aerosol size distribution in the RA tunnel. The SMPS sampled in total for about $16 \mathrm{~h}$, on the 7, 12 and 13 July 2011, mostly during daytime. The average particle number concentration was $366000 \mathrm{~cm}^{-3}$ with an average diameter of $38.7 \mathrm{~nm}$.

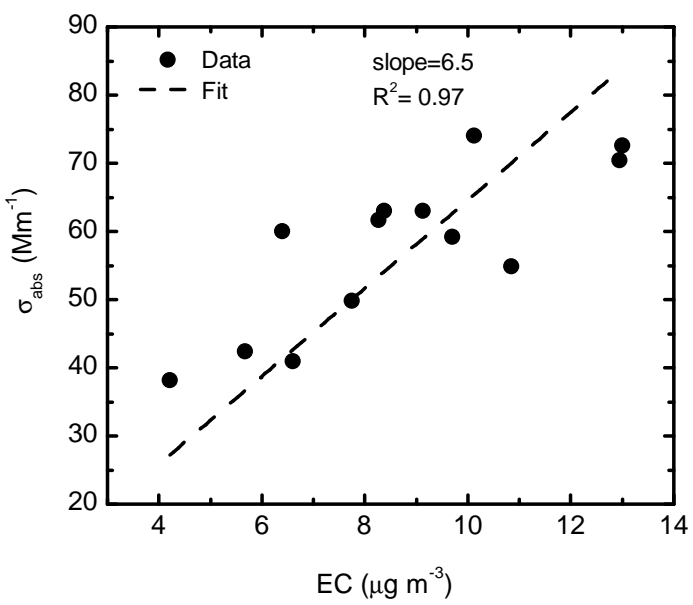

Fig. 9. Correlation between the light absorption measured by the MAAP and EC determined using the collected filters by means of a Sunset analyser (Sunset Laboratory Inc.).

The results, indicated in Fig. 9, show a good correlation between corrected $\sigma_{\mathrm{abs}}$ and EC. Through a linear fit a MAC of $6.5 \mathrm{~m}^{2} \mathrm{~g}^{-1}$ is obtained, a value in good agreement with the reported by the MAAP manufacturer. Such agreement is probably due exclusively to vehicular source in the tunnel, where little impact of other absorbing compounds at $637 \mathrm{~nm}$ is expected (Sandradewi et al., 2008; Gustafsson et al., 2009; Adler et al., 2010; Moosmüller and Chakrabarty, 2011).

\subsubsection{Aerosol light absorption and scattering}

In the recent literature, several studies have focused on mass concentration, chemical speciation and EBC content of aerosols released by vehicular emissions. Nevertheless, only a few aim to characterise aerosol optical properties like scattering coefficients and albedo (e.g. Japar et al., 1981, 1984). 

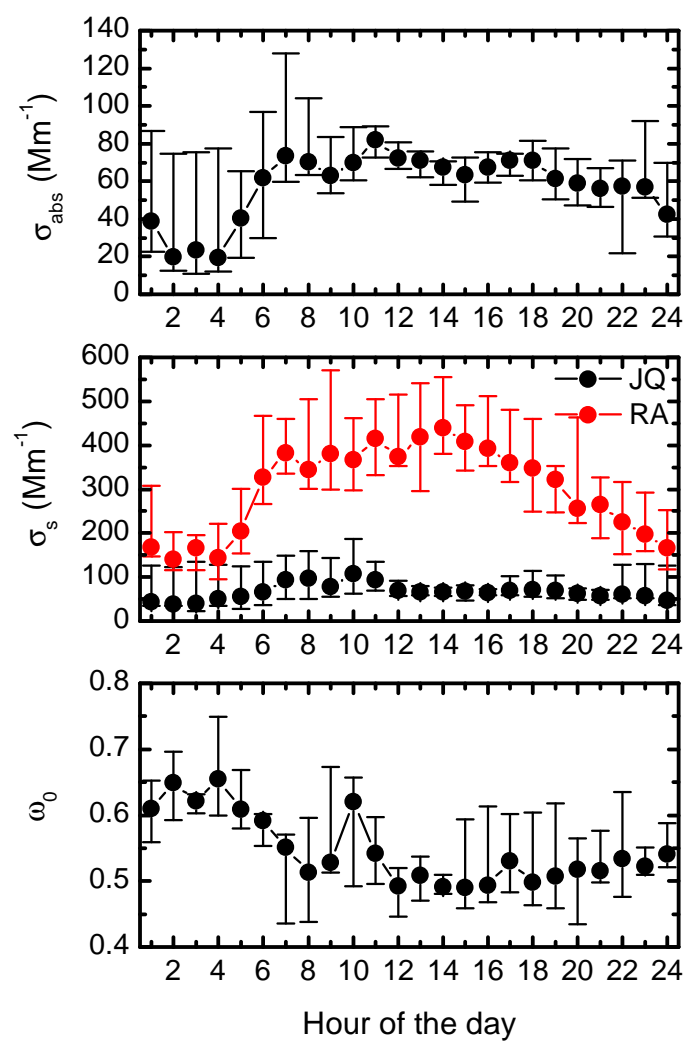

Fig. 10. Median values for (top) light absorption, (middle) light scattering and (bottom) single scattering albedo. The range bars represent the 10th and 90th percentiles.

Since aerosol optical properties can usually be measured with high time resolution, it can provide insights into aerosol dynamical processes. Moreover, the single scattering albedo is an intrinsic aerosol property, and a key parameter to determine the effect of vehicular particulate emissions on the radiative balance and climate. To our knowledge, this study provides the first report of single scattering albedo for particles released by vehicular emissions from a blend of gasoline and ethanol fuels.

The median diurnal cycle of aerosol optical properties inside the tunnels are shown in Fig. 10. In the RA tunnel, aerosol light scattering diurnal variation follows very closely HDV traffic as a result of the high particle number emission factor. As previously mentioned, absorption measurements at the RA tunnel could not be validated due to the exceedingly high equivalent black carbon concentrations. Nevertheless, using the EC determined from filters and a MAC of $6.5 \mathrm{~m}^{2} \mathrm{~g}^{-1}$ determined in the JQ tunnel, an average light absorption during filter sampling (08:00-20:00 LT) of $770 \mathrm{Mm}^{-1}$ has been calculated. As such, an average single scattering albedo of 0.31 can be estimated for the RA tunnel.

In the JQ tunnel, the aerosol light absorption and scattering presents a strong enhancement during the first morning hours, following the traffic intensity (Fig. 3). Correspond- ingly, $\omega_{0}$ decreases from 0.65 to 0.5 . The $\omega_{0}$ values observed overnight reflect reduced vehicular emissions, being comparable to previously reported ambient measurements in the SPMA (0.59-0.76, Backman et al., 2012). Throughout most of the day, single scattering albedo remains close to 0.5 , with the exception at 10:00 LT, when $\omega_{0}$ close to ambient values are observed. Such peak arises from a daily traffic direction inversion, which reduces traffic and modifies air exchange pattern, increasing (shortly) the importance of background aerosol.

The $\omega_{0}$ of 0.5 associated with the LDV Brazilian fleet is considerably higher than previously measured in tunnels. Japar et al. (1981) indicated an average albedo of 0.43 for particles released from gasoline-powered vehicles and of 0.28 from diesel-powered vehicles. Strawa et al. (2010), on the other hand, measured an average albedo of 0.31 for gasoline-fuelled LDVs in tunnels in the US. The chemical composition of the different fuel combustion sources has impacts on the chemical properties of the emitted aerosols, as well as on dynamical processes that subsequently change aerosol physical properties such as the single scattering albedo. More studies are necessary to investigate these issues.

\section{Conclusions}

The particulate matter in tunnels dominated whether by LDVs or HDVs emission was characterised for its chemical and physical properties. The measurements were carried out in May 2011 in the JQ tunnel, mainly impacted from LDV emissions, and in July 2011 in the RA tunnel, dominated by HDV emissions. In that given year, the fuel consumption by the road transportation sector in the São Paulo state was 8300 millions $\mathrm{m}^{3}$ of ethanol, 7500 millions $\mathrm{m}^{3}$ of gasoline, 11300 millions $^{3}$ of diesel and an estimated 600 millions $^{3}$ of biodiesel (mainly from soy bean). The minimum amount of ethanol in gasoline available in petrol stations is $20 \%$ whereas the minimum amount of biodiesel in diesel is $5 \%$.

The most abundant elements found in the RA tunnel were $\mathrm{S}, \mathrm{Fe}$ and $\mathrm{Si}$, respectively. An EF analysis relative to the UCC composition using $\mathrm{Al}$ as reference has been performed. Results from such analysis indicate that all elements are consistently below the EF calculated from Landis et al. (2007), except $\mathrm{K}$, the element previously linked to biofuel usage in ambient measurements (Andrade et al., 2012). This suggests indeed a higher emission of $\mathrm{K}$ from Brazilian HDVs, as in the US. Nevertheless, the EF of K is quite low (6), indicating, according to the analysis described here, a major crustal origin with negligible vehicular contribution. In the RA tunnel, the elements $\mathrm{Na}, \mathrm{Mg}, \mathrm{Al}, \mathrm{Si}, \mathrm{K}, \mathrm{Ca}, \mathrm{Ti}$ and $\mathrm{Ni}$ were assigned to mostly crustal origin whereas elements with both vehicular and crustal sources were $\mathrm{P}, \mathrm{Cl}, \mathrm{V}, \mathrm{Cr}, \mathrm{Mn}$ and $\mathrm{Fe}$. In the JQ tunnel, the most abundant trace elements were $\mathrm{Fe}$, 
$\mathrm{S}, \mathrm{Si}, \mathrm{Cu}$ and $\mathrm{Ca}$. With the exception of $\mathrm{Cu}$, such results are in good agreement with gasohol- and ethanol-fuelled vehicles measurements in dynamometers (Ferreira da Silva et al., 2010) and in previous tunnel studies (Sánchez-Ccoyllo et al., 2009). The high abundance of $\mathrm{Cu}$, linked to break lining, is attributed to a stop-go driving pattern in the JQ tunnel due to traffic congestions. A ratio of $\mathrm{Cu}: \mathrm{Sb}$ of 8.2 has been obtained, considerably higher than apportioned to brake linings elsewhere (4.6 \pm 2.3 , Sternbeck et al., 2002). Results from the EF analysis of the JQ and RA tunnels show similar trends as observed in previous studies. The elements apportioned to crustal source in the JQ tunnel are $\mathrm{Na}, \mathrm{Mg}, \mathrm{Al}, \mathrm{Si}$, $\mathrm{K}$ and $\mathrm{Ca}$ whereas elements with both vehicular and crustal sources were $\mathrm{P}, \mathrm{Cl}, \mathrm{Ti}, \mathrm{Mn}, \mathrm{Fe}$ and $\mathrm{Ni}$. The $\mathrm{EF}$ analysis of the JQ tunnel does not suggest a higher emission rate of $\mathrm{K}$ from gasohol- and ethanol-fuelled vehicles in comparison to gasoline-powered vehicles. Whether the higher EF from $\mathrm{K}$ in the RA tunnel is a result of biofuel usage cannot be determined here and demands further analysis.

The $\mathrm{PM}_{2.5}$ concentration in the RA tunnel was over four times higher than in the JQ tunnel $\left(233 \mu \mathrm{g} \mathrm{m}^{-3}\right.$ and $52 \mu \mathrm{g} \mathrm{m}^{-3}$, respectively). The most abundant species in the JQ tunnel was OM, accounting for $42 \%$ of $\mathrm{PM}_{2.5}$, followed by EC (17\%) and crustal elements (13\%). Sulphate accounted for $7 \%$ and the sum of the other trace elements $10 \%$. The difference between $\mathrm{PM}_{2.5}$ mass determined gravimetrically and the sum of identified compounds represented $10 \%$ of the mass. In the RA tunnel, most of the $\mathrm{PM}_{2.5}$ was composed of EC (52\%) and OM (39\%). sulphate, crustal and trace elements showed a minor contribution with $5 \%, 2 \%$ and $1 \%$, respectively. The unapportioned mass accounted for $1.0 \%$ of $\mathrm{PM}_{2.5}$. Accounting for the mass of the identified compounds, an upper limit of the OC: OM ratio has been calculated. In the RA tunnel, heavily impacted by diesel emissions, the OM : OC upper limit is 1.6, whereas in the JQ tunnel an $\mathrm{OM}$ : OC ratio upper limit of 2.0 was obtained.

The average OC: EC ratio for samples collected in the JQ tunnel was $1.59 \pm 0.09$, indicating an important contribution of EC despite the high ethanol fraction in the fuel composition. Previous tunnel measurements focusing on gasolinefuelled LDVs reported an OC: EC ratio in the fine particulate matter of 2.4 (Landis et al., 2007), a ratio $50 \%$ higher than observed in the JQ tunnel. Furthermore, the OC : EC ratio obtained for the JQ tunnel falls close to the lower bound of the literature values for LDVs $(\mathrm{OC}$ : EC ratio $>1)$, including a broad range of fuels (gasoline and diesel with different degrees of sulphur content) and aerosol size cuts $(2.5 \mu \mathrm{m}$ and $10 \mu \mathrm{m})$. The OC: EC ratio observed in samples from the RA tunnel is very close to diesel-fuelled HDV results observed in many previous studies reporting values close to 0.5 , indicating a small impact of the biodiesel in the combustion efficiency and in the carbonaceous material partitioning.

The sum of PAHs concentration was $56 \pm 5 \mathrm{ng} \mathrm{m}^{-3}$ in the RA tunnel and $45 \pm 9 \mathrm{ng} \mathrm{m}^{-3}$ in the JQ tunnel. BaP, the most studied PAH due to the carcinogenic potential, was found ranging from 0.9 to $6.7 \mathrm{ng} \mathrm{m}^{-3}\left(0.02-0.1 \%\right.$ of $\left.\mathrm{PM}_{2.5}\right)$ in the JQ tunnel whereas in the RA tunnel $\mathrm{BaP}$ ranged from 0.9 to $4.9 \mathrm{ng} \mathrm{m}^{-3}\left(0.004-0.02 \%\right.$ of $\left.\mathrm{PM}_{2.5}\right)$, indicating an important relative contribution of LDVs emission to atmospheric $\mathrm{BaP}$.

The average particle count yielded $73000 \mathrm{~cm}^{-3}$ in the JQ tunnel and $366000 \mathrm{~cm}^{-3}$ in the RA tunnel, with an average diameter of $48.4 \mathrm{~nm}$ in the former and $38.7 \mathrm{~nm}$ in the latter. As such, the vast majority of submicron aerosol particles are found in the nucleation mode in both tunnels, providing a large surface area for condensation and with important health effects. Besides aerosol size distribution, instrumentation for optical properties measurements was deployed in both tunnels. In the RA tunnel, aerosol light scattering diurnal variation follows HDV traffic very closely as a result of the high particle number emission factor. Median values range from $150 \mathrm{Mm}^{-1}$ up to $400 \mathrm{Mm}^{-1}$. As stated previously, real-time light absorption measurement was not possible in the RA tunnel; however, using the EC determined from filters and a MAC of $6.5 \mathrm{~m}^{2} \mathrm{~g}^{-1}$ determined in the JQ tunnel, an average light absorption during filter sampling (08:00-20:00 LT) of $770 \mathrm{Mm}^{-1}$ was calculated. A single scattering albedo of 0.31 was estimated for the RA tunnel. The aerosol light absorption in the JQ tunnel was observed to range from $20 \mathrm{Mm}^{-1}$ up to $80 \mathrm{Mm}^{-1}$ whereas light scattering was observed to range from $50 \mathrm{Mm}^{-1}$ up to $100 \mathrm{Mm}^{-1}$. A single scattering albedo of 0.5 is associated with the circulating fleet in the JQ tunnel, mainly composed of ethanol- and gasohol-fuelled LDVs.

Acknowledgements. This work was supported by the Research Foundation of the State of São Paulo (FAPESP, project 2008/581048 ) and by the National Council for Scientific and Technological Development (CNPq, project 402383/2009-5). We acknowledge the support of CET and CCR for the measurement logistics. We thank Alcides Ribeiro, Ana Lucia Loureiro, Fernando Morais, Fábio Jorge and Rosana Astolfo for their technical support. We thank Christy Long for running the OCEC analysis. We gratefully acknowledge the São Paulo Environmental State Agency (CETESB) in supporting these measurements.

Edited by: S. Gilardoni

\section{References}

Abu-Allaban, M., Coulomb, W., Gertler, A. W., Gillies, J., Pierson, W. R., Rogers, C. F., Sagebiel, J. C., and Tarnay, L.: Exhaust Particle Size Distribution Measurements at the Tuscarora Mountain Tunnel, Aerosol Sci. Tech., 36, 771-789, doi:10.1080/02786820290038401, 2002.

Adler, G., Riziq, A. A., Erlick, C., and Rudich, Y.: Effect of intrinsic organic carbon on the optical properties of fresh diesel soot, P. Natl. Acad. Sci., 107, 6699-6704, doi:10.1073/pnas.0903311106, 2010.

Allen, J. O., Mayo, P. R., Hughes, L. S., Salmon, L. G., and Cass, G. R.: Emissions of Size-Segregated Aerosols from On-Road Ve- 
hicles in the Caldecott Tunnel, Environ. Sci. Technol., 35, 41894197, doi:10.1021/es0015545, 2001.

Anderson, T. L. and Ogren, J. a.: Determining Aerosol Radiative Properties Using the TSI 3563 Integrating Nephelometer, Aerosol Sci. Technol., 29, 57-69, doi:10.1080/02786829808965551, 1998.

Anderson, T. L., Masonis, S. J., Covert, D. S., Ahlquist, N. C., Howell, S. G., Clarke, A. D., and McNaughton, C. S.: Variability of aerosol optical properties derived from in situ aircraft measurements during ACE-Asia, J. Geophys. Res.-Atmos., 108, doi:10.1029/2002JD003247, 2003.

Andrade, M. D. F., de Miranda, R. M., Fornaro, A., Kerr, A., Oyama, B., de Andre, P. A., and Saldiva, P.: Vehicle emissions and $\mathrm{PM}(2.5)$ mass concentrations in six Brazilian cities, Air quality, Atmosphere, \& Health, 5, 79-88, doi:10.1007/s11869-0100104-5, 2012.

Backman, J., Rizzo, L. V., Hakala, J., Nieminen, T., Manninen, H. E., Morais, F., Aalto, P. P., Siivola, E., Carbone, S., Hillamo, R., Artaxo, P., Virkkula, A., Petäjä, T., and Kulmala, M.: On the diurnal cycle of urban aerosols, black carbon and the occurrence of new particle formation events in springtime São Paulo, Brazil, Atmos. Chem. Phys., 12, 11733-11751, doi:10.5194/acp12-11733-2012, 2012.

Bae, M.-S., Demerjian, K. L., and Schwab, J. J.: Seasonal estimation of organic mass to organic carbon in $\mathrm{PM}_{2.5}$ at rural and urban locations in New York state, Atmos. Environ., 40, 74677479, doi:10.1016/j.atmosenv.2006.07.008, 2006.

Beirle, S., Boersma, K. F., Platt, U., Lawrence, M. G., and Wagner, T.: Megacity Emissions and Lifetimes of Nitrogen Oxides Probed from Space., Science (New York, N.Y.), 333, 1737-1739, doi:10.1126/science.1207824, 2011.

Birch, M. E. and Cary, R. a.: Elemental carbon-based method for occupational monitoring of particulate diesel exhaust: methodology and exposure issues, The Analyst, 121, 1183, doi:10.1039/an9962101183, 1996.

Butler, T. M., Stock, Z. S., Russo, M. R., Denier van der Gon, H. A. C., and Lawrence, M. G.: Megacity ozone air quality under four alternative future scenarios, Atmos. Chem. Phys., 12, 44134428, doi:10.5194/acp-12-4413-2012, 2012.

Cadle, S. H., Mulawa, P. A., Hunsanger, E. C., Nelson, K., Ragazzi, R. A., Barrett, R., Gallagher, G. L., Lawson, D. R., Knapp, K. T., and Snow, R.: Composition of Light-Duty Motor Vehicle Exhaust Particulate Matter in the Denver, Colorado Area, Environ. Sci. Technol., 33, 2328-2339, doi:10.1021/es9810843, 1999.

Castanho, A. D. and Artaxo, P.: Wintertime and summertime São Paulo aerosol source apportionment study, Atmos. Environ., 35, 4889-4902, doi:10.1016/S1352-2310(01)00357-0, 2001.

Cheng, Y.-H., Liu, Z.-S., and Chen, C.-C.: On-road measurements of ultrafine particle concentration profiles and their size distributions inside the longest highway tunnel in Southeast Asia, Atmos. Environ., 44, 763-772, doi:10.1016/j.atmosenv.2009.11.040, 2010.

Crippa, M., DeCarlo, P. F., Slowik, J. G., Mohr, C., Heringa, M. F., Chirico, R., Poulain, L., Freutel, F., Sciare, J., Cozic, J., Di Marco, C. F., Elsasser, M., Nicolas, J. B., Marchand, N., Abidi, E., Wiedensohler, A., Drewnick, F., Schneider, J., Borrmann, S., Nemitz, E., Zimmermann, R., Jaffrezo, J.-L., Prévôt, A. S. H., and Baltensperger, U.: Wintertime aerosol chemical composition and source apportionment of the organic fraction in the metropolitan area of Paris, Atmos. Chem. Phys., 13, 961-981, doi:10.5194/acp-13-961-2013, 2013.

Daher, N., Hasheminassab, S., Shafer, M. M., Schauer, J. J., and Sioutas, C.: Seasonal and spatial variability in chemical composition and mass closure of ambient ultrafine particles in the megacity of Los Angeles, Environ. Sci. Processes Impacts, 15, 283-295, doi:10.1039/C2EM30615H, 2013.

de Abrantes, R., Vicente de Assunção, J. a., Pesquero, C. R., Bruns, R. E., and Nóbrega, R. P.: Emission of polycyclic aromatic hydrocarbons from gasohol and ethanol vehicles, Atmos. Environ., 43, 648-654, doi:10.1016/j.atmosenv.2008.10.014, 2009.

Dobbins, R. A., Fletche Jr.r, R. A.,, B. A. B., and Hoeft, S.: Polycyclic aromatic hydrocarbons in flames, in diesel fuels, and in diesel emissions, Combustion and Flame, 144, 773-781, 2006.

Dodd, J. A., Ondov, J. M., Tuncel, G., Dzubay, T. G., and Stevens, R. K.: Multimodal size spectra of submicrometer particles bearing various elements in rural air, Environ. Sci. Technol., 25, 890903, doi:10.1021/es00017a010, 1991.

El Haddad, I., Marchand, N., Wortham, H., Piot, C., Besombes, J.L., Cozic, J., Chauvel, C., Armengaud, A., Robin, D., and Jaffrezo, J.-L.: Primary sources of $\mathrm{PM}_{2.5}$ organic aerosol in an industrial Mediterranean city, Marseille, Atmos. Chem. Phys., 11, 2039-2058, doi:10.5194/acp-11-2039-2011, 2011.

Ferreira da Silva, M., Vicente de Assunção, J. a., de Fátima Andrade, M., and Pesquero, C. R.: Characterization of Metal and Trace Element Contents of Particulate Matter (PM10) Emitted by Vehicles Running on Brazilian Fuels-Hydrated Ethanol and Gasoline with $22 \%$ of Anhydrous Ethanol, Journal of Toxicology and Environmental Health, Part A, 73, 901-909, doi:10.1080/15287391003744849, 2010.

Garg, B. D., Cadle, S. H., Mulawa, P. A., Groblicki, P. J., Laroo, C., and Parr, G. A.: Brake Wear Particulate Matter Emissions, Environ.1 Sci. Technol., 34, 4463-4469, doi:10.1021/es001108h, 2000.

Gelencsér, A., May, B., Simpson, D., Sánchez-Ochoa, A., Kasper-Giebl, A., Puxbaum, H., Caseiro, A., Pio, C., and Legrand, M.: Source apportionment of $\mathrm{PM}_{2.5}$ organic aerosol over Europe: Primary/secondary, natural/anthropogenic, and fossil/biogenic origin, J. Geophys. Res., 112, D23S04, doi:10.1029/2006JD008094, 2007.

Geller, M. D., Sardar, S. B., Phuleria, H., Fine, P. M., and Sioutas, C.: Measurements of Particle Number and Mass Concentrations and Size Distributions in a Tunnel Environment, Environ. Sci. Technol., 39, 8653-8663, doi:10.1021/es050360s, 2005.

Gillies, J. A. and Gertler, A. W.: Comparison and Evaluation of Chemically Speciated Mobile Source $\mathrm{PM}_{2.5}$ Particulate Matter Profiles, J. Air Waste Manage. Assoc., 50, 1459-1480, doi:10.1080/10473289.2000.10464186, 2000.

Grieshop, A. P., Lipsky, E. M., Pekney, N. J., Takahama, S., and Robinson, A. L.: Fine particle emission factors from vehicles in a highway tunnel: Effects of fleet composition and season, Atmos. Environ., 40, Supplement 2, 287-298, doi:10.1016/j.atmosenv.2006.03.064, 2006.

Guarieiro, A. L., ao V. da S. Santos, J., Eiguren-Fernandez, A., Torres, E. A., da Rocha, G. O., and de Andrade, J. B.: Redox activity and $\{\mathrm{PAH}\}$ content in size-classified nanoparticles emitted by a diesel engine fuelled with biodiesel and diesel blends, Fuel, 116, 490-497, 2014. 
Gurjar, B., Butler, T., Lawrence, M., and Lelieveld, J.: Evaluation of emissions and air quality in megacities, Atmos. Environ., 42, 1593-1606, doi:10.1016/j.atmosenv.2007.10.048, 2008.

Gustafsson, O., Kruså, M., Zencak, Z., Sheesley, R. J., Granat, L., Engström, E., Praveen, P. S., Rao, P. S. P., Leck, C., and Rodhe, H.: Brown clouds over South Asia: biomass or fossil fuel combustion?, Science (New York, N.Y.), 323, 495-8, doi:10.1126/science.1164857, 2009.

Handler, M., Puls, C., Zbiral, J., Marr, I., Puxbaum, H., and Limbeck, A.: Size and composition of particulate emissions from motor vehicles in the Kaisermühlen-Tunnel, Vienna, Atmos. Environ., 42, 2173-2186, doi:10.1016/j.atmosenv.2007.11.054, 2008.

He, L.-Y., Hu, M., Zhang, Y.-H., Huang, X.-F., and Yao, T.-T.: Fine Particle Emissions from On-Road Vehicles in the Zhujiang Tunnel, China, Environ. Sci. Technol., 42, 4461-4466, doi:10.1021/es7022658, 2008.

Healy, R. M., Sciare, J., Poulain, L., Kamili, K., Merkel, M., Müller, T., Wiedensohler, A., Eckhardt, S., Stohl, A., Sarda-Estève, R., McGillicuddy, E., O'Connor, I. P., Sodeau, J. R., and Wenger, J. C.: Sources and mixing state of size-resolved elemental carbon particles in a European megacity: Paris, Atmos. Chem. Phys., 12, 1681-1700, doi:10.5194/acp-12-1681-2012, 2012.

Ho, K., Ho, S. S. H., Lee, S., Cheng, Y., Chow, J. C., Watson, J. G., Louie, P., and Tian, L.: Emissions of gas- and particlephase polycyclic aromatic hydrocarbons (PAHs) in the Shing Mun Tunnel, Hong Kong, Atmos. Environ., 43, 6343-6351, doi:10.1016/j.atmosenv.2009.09.025, 2009.

Huang, X.-F., Yu, J. Z., He, L.-Y., and Hu, M.: Size Distribution Characteristics of Elemental Carbon Emitted from Chinese Vehicles: Results of a Tunnel Study and Atmospheric Implications, Environ. Sci. Technol., 40, 5355-5360, doi:10.1021/es0607281, 2006.

Hyvärinen, A.-P., Vakkari, V., Laakso, L., Hooda, R. K., Sharma, V. P., Panwar, T. S., Beukes, J. P., van Zyl, P. G., Josipovic, M., Garland, R. M., Andreae, M. O., Pöschl, U., and Petzold, A.: Correction for a measurement artifact of the Multi-Angle Absorption Photometer (MAAP) at high black carbon mass concentration levels, Atmos. Meas. Tech., 6, 81-90, doi:10.5194/amt-681-2013, 2013.

Japar, S. M., Szkarlat, A. C., and Jr., R. A. G.: Optical properties of particulate emissions from on-road vehicles, Atmospheric Environment (1967), 15, 2063-2070, doi:10.1016/00046981(81)90239-0, 1981.

Japar, S. M., Szkarlat, A. C., and Pierson, W. R.: The determination of the optical properties of airborne particle emissions from diesel vehicles, Sci. Total Environ., 36, 121-130, doi:10.1016/0048-9697(84)90256-0, 1984.

Jones, A. M. and Harrison, R. M.: Interpretation of particulate elemental and organic carbon concentrations at rural, urban and kerbside sites, Atmos. Environ., 39, 7114-7126, doi:10.1016/j.atmosenv.2005.08.017, 2005.

Kirstine, W. V. and Galbally, I. E.: The global atmospheric budget of ethanol revisited, Atmos. Chem. Phys., 12, 545-555, doi:10.5194/acp-12-545-2012, 2012.

Kleeman, M. J., Schauer, J. J., and Cass, G. R.: Size and Composition Distribution of Fine Particulate Matter Emitted from Motor Vehicles, Environ. Sci. Technol., 34, 1132-1142, doi:10.1021/es981276y, 2000.
Kristensson, A., Johansson, C., Westerholm, R., Swietlicki, E., Gidhagen, L., Wideqvist, U., and Vesely, V.: Real-world traffic emission factors of gases and particles measured in a road tunnel in Stockholm, Sweden, Atmos. Environ., 38, 657-673, doi:10.1016/j.atmosenv.2003.10.030, 2004.

Kuhn, T., Biswas, S., Fine, P. M., Geller, M., and Sioutas, C.: Physical and Chemical Characteristics and Volatility of PM in the Proximity of a Light-Duty Vehicle Freeway, Aerosol Sci. Technol., 39, 347-357, doi:10.1080/027868290930024, 2005.

Kupiainen, K. J., Tervahattu, H., Räisänen, M., Mäkelä, T., Aurela, M., and Hillamo, R.: Size and composition of airborne particles from pavement wear, tires, and traction sanding, Environ. Sci. Technol., 39, 699-706, 2005.

Landis, M. S., Lewis, C. W., Stevens, R. K., Keeler, G. J., Dvonch, J. T., and Tremblay, R. T.: Ft. McHenry tunnel study: Source profiles and mercury emissions from diesel and gasoline powered vehicles, Atmos. Environ., 41, 8711-8724, doi:10.1016/j.atmosenv.2007.07.028, 2007.

Lipsky, E. M. and Robinson, A. L.: Effects of dilution on fine particle mass and partitioning of semivolatile organics in diesel exhaust and wood smoke, Environ. Sci. Technol., 40, 155-62, 2006.

Magi, B. I.: Vertical profiles of light scattering, light absorption, and single scattering albedo during the dry, biomass burning season in southern Africa and comparisons of in situ and remote sensing measurements of aerosol optical depths, J. Geophys. Res., 108, 8504, doi:10.1029/2002JD002361, 2003.

Manahan, S.: Environmental chemistry, CRC press, 2005.

Martins, L. D., Andrade, M. F., Freitas, E. D., Pretto, A., Gatti, L. V., Albuquerque, E. L., Tomaz, E., Guardani, M. L., Martins, M. H. R. B., and Junior, O. M. A.: Emission Factors for Gas-Powered Vehicles Traveling Through Road Tunnels in São Paulo, Brazil, Environ. Sci. Technol., 40, 6722-6729, doi:10.1021/es052441u, 2006.

Matti Maricq, M.: Chemical characterization of particulate emissions from diesel engines: A review, J. Aerosol Sci., 38, 10791118, doi:10.1016/j.jaerosci.2007.08.001, 2007.

Moosmüller, H. and Chakrabarty, R. K.: Technical Note: Simple analytical relationships between Ångström coefficients of aerosol extinction, scattering, absorption, and single scattering albedo, Atmos. Chem. Phys., 11, 10677-10680, doi:10.5194/acp-1110677-2011, 2011.

Mulawa, P. A., Cadle, S. H., Knapp, K., Zweidinger, R., Snow, R., Lucas, R., and Goldbach, J.: Effect of Ambient Temperature and E-10 Fuel on Primary Exhaust Particulate Matter Emissions from Light-Duty Vehicles, Environ. Sci. Technol., 31, 13021307, doi:10.1021/es960514r, 1997.

Müller, T., Henzing, J. S., de Leeuw, G., Wiedensohler, A., Alastuey, A., Angelov, H., Bizjak, M., Collaud Coen, M., Engström, J. E., Gruening, C., Hillamo, R., Hoffer, A., Imre, K., Ivanow, P., Jennings, G., Sun, J. Y., Kalivitis, N., Karlsson, H., Komppula, M., Laj, P., Li, S.-M., Lunder, C., Marinoni, A., Martins dos Santos, S., Moerman, M., Nowak, A., Ogren, J. A., Petzold, A., Pichon, J. M., Rodriquez, S., Sharma, S., Sheridan, P. J., Teinilä, K., Tuch, T., Viana, M., Virkkula, A., Weingartner, E., Wilhelm, R., and Wang, Y. Q.: Characterization and intercomparison of aerosol absorption photometers: result of two intercomparison workshops, Atmos. Meas. Tech., 4, 245-268, doi:10.5194/amt-4-245-2011, 2011. 
Nicholson, K., Branson, J., Giess, P., and Cannell, R.: The effects of vehicle activity on particle resuspension, J. Aerosol Sci., 20, 1425-1428, doi:10.1016/0021-8502(89)90853-7, 1989.

Ning, Z., Polidori, a., Schauer, J., and Sioutas, C.: Emission factors of PM species based on freeway measurements and comparison with tunnel and dynamometer studies, Atmos. Environ., 42, 3099-3114, doi:10.1016/j.atmosenv.2007.12.039, 2008.

Ntziachristos, L., Ning, Z., Geller, M. D., Sheesley, R. J., Schauer, J. J., and Sioutas, C.: Fine, ultrafine and nanoparticle trace element compositions near a major freeway with a high heavy-duty diesel fraction, Atmos. Environ., 41, 5684-5696, doi:10.1016/j.atmosenv.2007.02.043, 2007.

Oliveira, C., Martins, N., ao Tavares, J., Pio, C., Cerqueira, M., Matos, M., Silva, H., Oliveira, C., and Camões, F. C.: Size distribution of polycyclic aromatic hydrocarbons in a roadway tunnel in Lisbon, Portugal, Chemosphere, 83, 1588-1596, doi:10.1016/j.chemosphere.2011.01.011, 2011.

Pan, X. L., Kanaya, Y., Wang, Z. F., Liu, Y., Pochanart, P., Akimoto, H., Sun, Y. L., Dong, H. B., Li, J., Irie, H., and Takigawa, M.: Correlation of black carbon aerosol and carbon monoxide in the high-altitude environment of Mt. Huang in Eastern China, Atmos. Chem. Phys., 11, 9735-9747, doi:10.5194/acp-11-97352011, 2011.

Pandolfi, M., Cusack, M., Alastuey, A., and Querol, X.: Variability of aerosol optical properties in the Western Mediterranean Basin, Atmos. Chem. Phys., 11, 8189-8203, doi:10.5194/acp-11-81892011, 2011.

Petzold, A., Schloesser, H., Sheridan, P. J., Arnott, W. P., Ogren, J. A., and Virkkula, A.: Evaluation of Multiangle Absorption Photometry for Measuring Aerosol Light Absorption, Aerosol Sci. Technol., 39, 40-51, doi:10.1080/027868290901945, 2005.

Pio, C., Cerqueira, M., Harrison, R. M., Nunes, T., Mirante, F., Alves, C., Oliveira, C., Sanchez, A., Campa, D., Artíñano, B. n., and Matos, M.: OC/EC ratio observations in Europe : Re-thinking the approach for apportionment between primary and secondary organic carbon, Atmos. Environ., 45, 6121-6132, doi:10.1016/j.atmosenv.2011.08.045, 2011.

Ravindra, K., Sokhi, R., and Grieken, R. V.: Atmospheric polycyclic aromatic hydrocarbons: Source attribution, emission factors and regulation, Atmos. Environ., 42, 2895-2921, doi:10.1016/j.atmosenv.2007.12.010, 2008.

Rizzo, L. V., Artaxo, P., Müller, T., Wiedensohler, A., Paixão, M., Cirino, G. G., Arana, A., Swietlicki, E., Roldin, P., Fors, E. O., Wiedemann, K. T., Leal, L. S. M., and Kulmala, M.: Long term measurements of aerosol optical properties at a primary forest site in Amazonia, Atmos. Chem. Phys., 13, 2391-2413, doi:10.5194/acp-13-2391-2013, 2013.

Rogge, W. F., Hildemann, L. M., Mazurek, M. A., Cass, G. R., and Simoneit, B. R. T.: Sources of fine organic aerosol. 3. Road dust, tire debris, and organometallic brake lining dust: roads as sources and sinks, Environ. Sci. Technol., 27, 1892-1904, doi:10.1021/es00046a019, 1993a.

Rogge, W. F., Hildemann, L. M., Mazurek, M. A., Cass, G. R., and Simoneit, B. R. T.: Sources of fine organic aerosol. 2. Noncatalyst and catalyst-equipped automobiles and heavyduty diesel trucks, Environ. Sci. Technol., 27, 636-651, doi:10.1021/es00041a007, 1993b.
Sánchez-Ccoyllo, O. R., Ynoue, R. Y., Martins, L. D., Astolfo, R., Miranda, R. M., Freitas, E. D., Borges, A. S., Fornaro, A., Freitas, H., Moreira, A., and Andrade, M. F.: Vehicular particulate matter emissions in road tunnels in Sao Paulo, Brazil, Environ. Monit. Assess., 149, 241-9, doi:10.1007/s10661-008-0198$5,2009$.

Sandradewi, J., Prévôt, A. S. H., Szidat, S., Perron, N., Alfarra, M. R., Lanz, V. a., Weingartner, E., and Baltensperger, U.: Using aerosol light absorption measurements for the quantitative determination of wood burning and traffic emission contributions to particulate matter, Environ. Sci. Technol., 42, 3316-3323, 2008.

Saylor, R., Edgerton, E., and Hartsell, B.: Linear regression techniques for use in the EC tracer method of secondary organic aerosol estimation, Atmos. Environ., 40, 7546-7556, doi:10.1016/j.atmosenv.2006.07.018, 2006.

Sheridan, P. J., Arnott, W. P., Ogren, J. A., Andrews, E., Atkinson, D. B., Covert, D. S., Moosmüller, H., Petzold, A., Schmid, B., Strawa, A. W., Varma, R., and Virkkula, A.: The Reno Aerosol Optics Study: An Evaluation of Aerosol Absorption Measurement Methods, Aerosol Sci. Technol., 39, 1-16, doi:10.1080/027868290901891, 2005.

Spolnik, Z., Belikov, K., Van Meel, K., Adriaenssens, E., De Roeck, F., and Van Grieken, R.: Optimization of measurement conditions of an energy dispersive X-ray fluorescence spectrometer with high-energy polarized beam excitation for analysis of aerosol filters, Appl. Spectrosc., 59, 1465-1469, doi:10.1366/000370205775142647, 2005.

Sternbeck, J., Sjödin, A. K., and Andréasson, K.: Metal emissions from road traffic and the influence of resuspension - results from two tunnel studies, Atmos. Environ., 36, 4735-4744, doi:10.1016/S1352-2310(02)00561-7, 2002.

Strawa, A., Kirchstetter, T., Hallar, A., Ban-Weiss, G., McLaughlin, J., Harley, R., and Lunden, M.: Optical and physical properties of primary on-road vehicle particle emissions and their implications for climate change, J. Aerosol Sci., 41, 36-50, doi:10.1016/j.jaerosci.2009.08.010, 2010.

Taylor, S. R. and McLennan, S. M.: The geochemical evolution of the continental crust, Rev. Geophys., 33, 241-265, doi:10.1029/95RG00262, 1995.

Vasconcellos, P. C., Zacarias, D., a. F. Pires, M., Pool, C. S., and Carvalho, L. R.: Measurements of polycyclic aromatic hydrocarbons in airborne particles from the metropolitan area of São Paulo City, Brazil, Atmos. Environ., 37, 3009-3018, doi:10.1016/S1352-2310(03)00181-X, 2003.

Ynoue, R. Y. and Andrade, M. F.: Size-Resolved Mass Balance of Aerosol Particles over the São Paulo Metropolitan Area of Brazil, Aerosol Sci. Technol., 38, 52-62, doi:10.1080/02786820490466756, 2004.

Zhang, J., He, K., Ge, Y., and Shi, X.: Influence of fuel sulfur on the characterization of PM 10 from a diesel engine, Fuel, 88, 504510, doi:10.1016/j.fuel.2008.09.001, 2009. 